\title{
NBSIR 76-999
}

\section{$\underline{\text { Surveillance Test Procedures }}$}

H. W. Almer

Edited by: Jerry Keller

Institute for Basic Standards

National Bureau of Standards

Washington, D.C. 20234

February 1976

Final

Issued May 1977

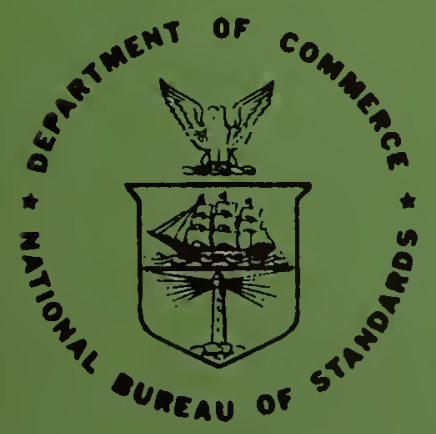

U. S. DEPARTMENT OF COMMERCE NATIONAL BUREAU OF STANDARDS 

NBSIR 76-999

\section{SURVEILLANCE TEST PROCEDURES}

H. W. Almer

Edited by: Jerry Keller

Institute for Basic Standards

National Bureau of Standards

Washington, D.C. 20234

February 1976

Final

Issued May 1977

U.S. DEPARTMENT OF COMMERCE, Juanita M. Kreps, Secretary

Dr. Betsy Ancker-Johnson. Assistant Secretary for Science and Technology NATIONAL BUREAU OF STANDARDS, Ernest Ambler, Acting Director 



\section{PROCFDURES}

H. E. Almer

\section{Abstract}

Surveillance tests are designed to monitor the values of mass standards between calibrations. Two types are described; both consist of comparisons of the weights of an ordered set of mass standards with each other. The differences found are compared with those computed from the reported mass values. Surveillance limits based on the precision of both the calibration and the surveillance test processes are computed. These limits are estimates of the departure of the measured differences from the expected, or predicted, differences as computed from the reported values. A larger change is considered significant. Additional measurements to identify individual weights which have changed are required when a given comparison indicates that the mass of one or more of the weights involved has changed. Buoyancy corrections are used to correct for the difference in the buoyant effect on weights of differing densities. Records document the surveillance test results, and control charts help detect trends. Judgments concerning recalibration can be made based on the constancy of the weights relative to the use requirements.

Key words: Apparent mass; buoyancy; buoyancy correction; change; comparison; difference; mass; records; set; surveillance limits; surveillance test; test interval; true mass; value; weighing design; weights. 

CONTENTS

1. Introduction

2. Measurement Procedures 1

2.1 Type I Surveillance Test 2

2.2 Type II Surveillance Test 4

3. Surveillance Limits 6

3.1 Uncertainties of Each of the Summations from the 6 Calibration Mass Measurement Process Known

3.2 Uncertainties for Individuals but not Sumations from 6 the Calibration Mass Measurement Process Known

3.2.1 Numerical Example 7

4. Identifying Weights Which Have Changed 8

4.1 Analysis of Measurement Results . 9

4.2 Numerical Examples 10

5. Buoyancy Corrections 11

5.1 Buoyancy Corrections Computed on True 11 Mass Basis

5.2 Buoyancy Corrections Computed on Apparent 13 Mass Basis

5.3 Application of Buoyancy Corrections 15

5.3.1 Buoyancy Correction Application for 15 True Mass

$\begin{array}{ll}\text { 5.3.2 Buoyancy Correction Application } & 16\end{array}$ for Apparent Mass

6. Records 17

7. Surveillance Test Interval 17

$\begin{array}{lr}\text { REFERENCES } & 20\end{array}$

Appendix 1. Weighing Designs for Surveillance Tests 21

Weighing Designs for Type I 22

Surveillance Tests

Weighing Designs for Type II 28

Surveillance Tests

Appendix 2. Surveillance Test Examples 36

Type I Surveillance Test Example 36

Type II Surveillance Test Example 51 

Surveillance test procedures are designed to monitor the values of mass standards between calibrations. This is important because the problem of the continuing validity of the values contained in the report of calibration is always present, and especially so for those who look to others for calibration service. Surveillance test procedures, if properly implemented, so provide a means of detecting gross changes as soon as possible with a minimum expendture of time and effort.

Two types of surveillance tests are described. The first type, designated Type $I$, uses a minimum number of measurements that involve all of the weights in the set. The second type, designated Type II, requires a larger number of measurements which are grouped so that they are a series of 3-1's weighing designs? This method has some redundancy.

Included in the surveillance test procedures are methods of identifying any weights whose mass values may have changed since they were calibrated, and methods of correcting for the buoyant effect of the atmosphere.

\section{MEASUREMENT PROCEDURES}

A surveillance test consists of a series of comparisons of the weights of an ordered set of mass standards with each other, according to an appropriate weighing design, and comparing the differences in mass value found by these comparisons with those computed from the values contained in the report of calibration [1]*. Ideally a suitable known weight, other than one of the weights in the set being tested, is used as the standard on which the values found by the surveillance test are based. This also establishes whether or not the whole set has changed proportionally. For sets where the largest weight is one kilogram or less, the nominal value of the weight used as a standard should be that of the largest weight in the set. For example, a set whose largest weight is $100 \mathrm{~g}$ is being tested. For this set, a $100 \mathrm{~g}$ weight whose mass value is known would be suitable for use as a standard. For sets having weights greater than one kilogram, a suitable one kilogram weight may be used as the standard. For sets in the avoirdupois system having weights greater than one pound, a suitable one pound weight may be used as the standard. Cenerally the uncertainty of the mass value of a one kilogram, or a one pound standard, is less than the uncertainty of the value of a larger standard.

1 A title given to the three intercomparisons of three objects $A, B$, and $C$, namely the measurements of the differences $A-B$, $A-C$, and $B-C$.

* Figures in brackets refer to similarly numbered references at the end of this paper. 
If a weight of the suggested denomination is not available, a suitable known weight of a different denomination, if available, may be used to establish whether or not the whole set has changed. The nominal value of this weight should be equal to that of one of the larger weights in the set being tested, say not less than $20 \mathrm{~g}$ for a set beginning at $100 \mathrm{~g}$, or less than $100 \mathrm{~g}$ for a set beginning at $1 \mathrm{~kg}$. Where the weight used as the standard has the same nominal value as the largest weight in the test set, up to one kilogram, the comparison between the standard and the largest weight of the set is a part of the surveillance test weighing design. Where the nominal value of the weight used to establish whether the whole set has changed is not the same as the largest weight of the test set, the comparison between it and the corresponding weight of the test set is a side measurement and not a part of the surveillance test weighing design.

Where a suitable known weight, other than the weights in the set being tested, is not available, the usual procedure is to base the values found by the surveillance test on the largest weight of the set under test, up to one kilogram. Weights larger than one kilogram may be based on the largest weight of the set. The weighings may be made by either the substitution or the transposition method of weighing [2].

In general, the capacities of the balances selected for surveillance tests should be the smallest available that will accommodate the maximum load to be placed on it. For example, when testing a set of weights ranging from $100 \mathrm{~g}$ to $1 \mathrm{mg}$, a balance having a capacity of from $100 \mathrm{~g}$ to $200 \mathrm{~g}$ would be used for loads from $100 \mathrm{~g}$ to $20 \mathrm{~g}$, and a balance of $20 \mathrm{~g}$ capacity for loads under $20 \mathrm{~g}$. If a balance of say $1 \mathrm{~g}$ and $2 \mathrm{~g}$ capacity were available, it would be used for the fractional weights.

\subsection{Type I Surveillance Test}

In a type I surveillance test, the first measurement is the comparison between the largest weight of the set and a summation of the next smaller weights, from the set, the sum of whose nominal values is equal to that of the largest veight. The next comparison would be between a selected weight from the summation, that is, the summation used in the first comparison, and another summation whose nominal value is equal to that of the selected weight.

This procedure of selecting a weight from each summation and comparing it with a summation of the next smaller weights is repeated until all of the weights of the set have been involved in a comparison. Any given comparison should involve the fewest weights that will permit all of the weights of the set to be included in the chain of comparisons. 
If a suitable weight having the same nominal value as the largest weight of the set is available for use as a standard, then the first comparison would be between this weight and the largest weight of the set.

If, for example, a set of weights ranging from $100 \mathrm{~g}$ to lmg is to be tested using the Type I surveillance test procedures where another $100 \mathrm{~g}$ weight is to be used as a standard, the ratios of the weights to each other are 5, $3,2,1$. The first comparison would be:

$$
100 \mathrm{~g}-\mathrm{s} 100 \mathrm{~g}=\mathrm{a}_{\mathrm{l}}
$$

The second comparison would be:

$$
\begin{gathered}
100 \mathrm{~g}-\Sigma 100 \mathrm{~g}=\mathrm{a}_{2} \\
\text { where } \quad \Sigma 100 \mathrm{~g}=50 \mathrm{~g}+30 \mathrm{~g}+20 \mathrm{~g}
\end{gathered}
$$

The third comparison would be:

$$
20 g-\sum 20 g=a_{3}
$$

where

$$
\sum 20 g=10 g+5 g+3 g+2 g
$$

This procedure is continued until all of the weights have been compared.

In this example the last comparison would be:

$$
3 m g-\Sigma 3 m g=a_{n}
$$

where $\quad \sum 3 \mathrm{mg}=2 \mathrm{mg}+1 \mathrm{mg}$.

The observed differences in mass values $\left(a_{1}, a_{2}, \ldots . a_{n}\right)$ found by these comparisons are compared with the accepted differences, as computed from the reported values, to determine the degree of agreement between the observed and the accepted differences. If the agreement is within the limits for surveillance (see section 3) any indicated changes may be regarded as being insignificant, and the continuing validity of the reported values may be assumed. If the agreement between the observed and the accepted differences is not within the surveillance limits, the indicated changes should-be regarded as significant, and the weights exhibiting a significant change should be recalibrated. When the result of a comparison indicates that one or more of the weights has changed significantly, additional measurements are made to identify the weight, or weights, that have changed. 
In a Type II surveillance test, the measurements of the first 3-1's weighing design series are between the largest weight of the set, another weight of the same nominal value, and a summation of the next smaller weights from the set also having the same nominal value as the largest weight of the set. The comparisons of the next 3-1's weighing would be between a selected weight from the summation, used in the first 3-1's series, and two other summations, of the next smaller weights, whose nominal values are the same as that of the selected weight. This procedure of selecting a weight from a summation and comparing it with other sumnations of the next smaller weights according to the 3-1's weighing design is repeated until all of the weights of the set have been involved in the comparisons.

For example, a set ranging from $100 \mathrm{~g}$ to $1 \mathrm{mg}$ is to be tested using the Type II surveillance test procedures, where another $100 \mathrm{~g}$ weight ${ }^{l}$ is to be used as a standard. The ratios of the weights to each other are $5,3,2$, and 1. The first series according to the $3-1$ 's weighing design would be:

$$
\begin{array}{ll} 
& S 100 \mathrm{~g}-100 \mathrm{~g}=\mathrm{a}_{1} \\
& \mathrm{~S} 100 \mathrm{~g}-\Sigma 100 \mathrm{~g}=\mathrm{a}_{2} \\
& 100 \mathrm{~g}-\Sigma 100 \mathrm{~g}=\mathrm{a}_{3} \\
\text { Where } \quad & \mathrm{S} 100 \mathrm{~g} \text { is the standard } \\
& 100 \mathrm{~g} \text { is the } 100 \mathrm{~g} \text { of the set being tested } \\
& \sum 100 \mathrm{~g}=50 \mathrm{~g}+30 \mathrm{~g}+20 \mathrm{~g}
\end{array}
$$

I If a suitable known $100 \mathrm{~g}$ weight is not available for use as a standard, the first series according to the 3-1's weighing design would be:

$$
\begin{aligned}
& 100 g-100 g^{\prime}=a_{1} \\
& 100 g-\Sigma .100 g-a_{2} \\
& 100 g^{\prime}-\Sigma 100 g=a_{3}
\end{aligned}
$$

where

$100 \mathrm{~g}^{\prime}$ is any $100 \mathrm{~g}$ weight, or a summation whose nominal value is $100 \mathrm{~g}$, used to fill the series $\sum 100 \mathrm{~g}=50 \mathrm{~g}+30 \mathrm{~g}+20 \mathrm{~g}$. The other series remain as indicated. 
The second series would be:

$$
\begin{gathered}
30 \mathrm{~g}-\Sigma 30 \mathrm{~g}_{1}=\mathrm{a}_{1} \\
30 \mathrm{~g}-\Sigma 30 \mathrm{~g}_{2}=\mathrm{a}_{2} \\
\Sigma 30 \mathrm{~g}_{1}-\Sigma 30 \mathrm{~g}_{2}=\mathrm{a}_{3} \\
\text { where } \quad \Sigma 30 \mathrm{~g}_{1}=20 \mathrm{~g}+10 \mathrm{~g} \\
\Sigma 30 \mathrm{~g}_{2}=20 \mathrm{~g}+5 \mathrm{~g}+3 \mathrm{~g}+2 \mathrm{~g}
\end{gathered}
$$

This procedure is continued for each decade until all of the weights in the set have been compared. Unless the set contains an extra $1 \mathrm{mg}$ weight or another $1 \mathrm{mg}$ weight whose mass value is known is available, the 3-1's weighing design cannot be used for the last decade. Where the set has only one $1 \mathrm{mg}$ weight and another is not available to fill the series, the comparisons for the last decade are:

$$
\begin{aligned}
& 5 m g-3 m g-2 m g=a_{1} \\
& 3 m g-2 m g-1 m g=a_{2}
\end{aligned}
$$

These two comparisons are treated as the comparisons in Type I surveillance test. Where the set has two $1 \mathrm{mg}$ weights, or another 1mg weight whose value is known, is available, the last series is:

$$
\begin{gathered}
3 m g-\Sigma 3 m g_{1}=a_{1} \\
3 m g-\Sigma 3 m g_{2}=a_{2} \\
\Sigma 3 m g_{1}-\Sigma 3 m g_{2}=a_{3} \\
\text { where } \quad \Sigma 3 m g_{1}=2 m g+1 m g_{1} \\
\\
\Sigma 3 m g_{2}=2 m g+1 m g_{2}
\end{gathered}
$$

The $1 \mathrm{mg}_{2}$ may be either the second $1 \mathrm{mg}$ weight of the set or another lmg weight whose mass value is known.

If a weight other than one of the same denomination as the largest weight in the set is used to establish whether or not all the weights of the set have changed proportionately, then some other known weight must be compared to a weight of the set or (e.g. in this case) a known $30 \mathrm{~g}$ is compared with the $30 \mathrm{~g}$ of the set.

$$
30 \mathrm{~g}-\mathrm{s} 30 \mathrm{~g}=\mathrm{a}
$$


If this difference agrees with the expected difference as computed from the reported values of the two weights, within the surveillance limit, (see section 3), and the observed differences of the other comparisons are in agreement with the predicted differences, it may be assumed that the set as a whole has not changed significantly.

Because in most of the series used in a Type II surveillance test one of the weights is part of both summations used in a given series, the weighings are made by the substitution method of weighing. For example, in the series involving the $30_{\mathrm{g}}$ weight, $\sum 30_{\mathrm{g}}$, and $\sum 30_{g_{2}}$, the $20 \mathrm{~g}$ weight is part of both summations.

\section{SURVEILLANCE LIMITS}

3.1 Uncertainties of Each of the Summations from the Calibration Process Known [1], [3]

Ideally the surveillance limits are calculated from the standard deviations of the calibration process and surveillance test process as follows:

$$
\mathrm{sl}=\mathrm{U}_{\mathrm{c}}+3 \sigma_{\mathrm{d}}
$$

where $U_{c}=$ uncertainty of calibration process

$$
\begin{aligned}
\sigma_{\mathrm{d}}= & \text { standard deviation of one weighing } \\
& \text { of the surveillance test process }
\end{aligned}
$$

3.2 Uncertainties for Individuals but not Summations from the Calibration Process Known

Sometimes only the uncertainties associated with the mass values of the weights, as reported in the Calibration Report, are available for estimating the uncertainties of the summations. In this situation, an approximate estimate of the uncertainties is found by taking the square root of the sum of the squares of the uncertainties of the values of the weights in a given comparison [4]. 
Suppose that the comparison is between a selected weight, $W_{1}$, and a summation consisting of three weights, $W_{2}, W_{3}$ and $W_{4}$, whose nominal value is equal to that of the selected weight, $W_{1}$. The uncertainty of each value is $U_{1}, U_{2}, U_{3}$ and $U_{4}$ respectively.

An approximate estimate of the uncertainty, $U_{C}$, for these weights is:

$$
u_{c}=\sqrt{u_{1}^{2}+u_{2}^{2}+u_{3}^{2}+u_{4}^{2}}
$$

where $U_{c}$ is the uncertainty of the calibration mass measurement process and

$\mathrm{U}_{\mathbf{j}}$ is the uncertainty for the individual weights as reported on the Report of Calibration.

With this procedure, the expression for the surveillance limit is:

$$
\mathrm{sl}=\mathrm{U}_{\mathrm{c}}+3 \sigma_{\mathrm{d}}
$$

where $U_{c}$ is the uncertainty as defined above, and

sl and $\sigma_{d}$ have the same meaning as in equation (1).

This process is equally applicable for any number of weights.

For most designs, this procedure gives a somewhat smaller uncertainty than the uncertainties from the calibration process.

\subsubsection{Numerical Example}

Assume that the following weights and their associated uncertainties are involved in the comparison $100 \mathrm{~g}-\sum 100 \mathrm{~g}$.

$\begin{array}{cc}\text { Weight } & \text { Uncertainty } \\ 100 \mathrm{~g} & 0.015 \\ 50 \mathrm{~g} & 0.011 \\ 30 \mathrm{~g} & 0.012 \\ 20 \mathrm{~g} & 0.010\end{array}$




$$
\begin{aligned}
\mathrm{u}_{c} & =\sqrt{0.015^{2}+0.011^{2}+0.012^{2}+0.010^{2}} \\
& =\sqrt{0.00025}+0.000121+0.000144+0.0001 \\
& =\sqrt{0.00059} \\
& =0.024 \mathrm{mg}
\end{aligned}
$$

This is an approximate estimate of the uncertainty of the calibration process for this comparison.

Now let us assume that the standard deviation of one weighing of the surveillance test process is $0.015 \mathrm{mg}$.

Then the surveillance limit, sl, is:

$$
\begin{aligned}
\text { sl } & =0.024+3(0.015) \\
s 1 & =0.024+0.045 \\
& =0.069 \mathrm{mg}
\end{aligned}
$$

4. Identifying the Weights Which Have Changed

If, in any comparison, the observed difference differs from the predicted value of the difference by more than the surveillance limits for that comparison, the weight, or weights, that have changed must be identified so that they can be recalibrated. The identity of the weights that have changed may be established by additional measurements. In general, these additional measurements are comparisons between the weights making up the summation that was compared with the selected weight.

Suppose, for example, that the observed difference of

$$
20 g-\sum 20 g=a
$$

where $\quad \sum 20 g=10 g+5 g+3 g+2 g$

differs from the predicted value of the difference by more than the surveillance limits. Assume, also, that the observed differences in the comparison in which the $20 \mathrm{~g}$ weight was a part of the summation, $100 \mathrm{~g}-\Sigma 100 \mathrm{~g}$, and the comparison $\mathrm{jn}$ which the $2 \mathrm{~g}$ weight was the selected weight, $2 \mathrm{~g}-\Sigma 2 \mathrm{~g}$, are in good agreement with their predicted, or accepted, differences as computed from the reported values. This indicates that neither the $20 \mathrm{~g}$ weight nor the $2 \mathrm{~g}$ weight have changed significantly. The following measurements are made and their results analyzed to identify the weight, or weights, whose masses have changed: 


$$
\begin{aligned}
10 g-(5 g+3 g+2 g) & =a^{\prime} \\
5 g-(3 g+2 g) & =a^{\prime \prime} \\
3 g-(2 g+1 g) & =a^{\prime}{ }^{\prime}
\end{aligned}
$$

\subsection{Analysis of Measurement Results}

If $a^{\prime}$ differs from the predicted value by more than the surveillance limits and $a^{\prime \prime}$ and $a^{\prime \prime \prime}$ agree with the predicted value within the surveillance limits, it is probable that the $10 \mathrm{~g}$ weight has changed. If both $\mathrm{a}^{\prime}$ and a'' differ from the corresponding predicted values by more than the surveillance limits by about the same amount, numerically, but with opposite signs, and a'" agrees with the predicted value within the surveillance limit, it is probable that the $5 \mathrm{~g}$ weight has changed. If $\mathrm{a}^{\prime}$ and $\mathrm{a}^{\prime \prime}$ differ from the corresponding predicted values by markedly difference amounts which are greater than the corresponding surveillance limits, and $a^{\prime \prime \prime}$ agrees with the corresponding predicted value within the surveillance limit, it is probable that both the $10 \mathrm{~g}$ and the $5 \mathrm{~g}$ weights have changed.

If $a^{\prime}, a^{\prime \prime}$, and $a^{\prime \prime \prime}$ all differ from the corresponding predicted values by more than the surveillance limits, but by about the same amount, it is probable that the $3 g$ weight is the one that has changed. If $a^{\prime}$ and $a^{\prime \prime}$ differ from the corresponding predicted values by about the same amount, but $a^{\prime \prime}$ differs from the corresponding predicted value by a markedly different amount, it is probable that both the $5 \mathrm{~g}$ weight and the $3 \mathrm{~g}$ weights have changed.

If the results of all three measurements differ from the corresponding predicted values by more than the corresponding surveillance limits, by markedly different amounts, it is probable that all three weights have changed and may require recalibration.

If all three ( $a^{\prime}, a^{\prime \prime}$, and $a^{\prime \prime \prime)}$ of the observed differences are in good agreement with the predicted differences, it is still possible that the weights involved in either of the comparisons

$$
100 \mathrm{~g}-\Sigma 100 \mathrm{~g}=\mathrm{a}_{1} \text { or } 2 \mathrm{~g}-\sum 2 \mathrm{~g}=\mathrm{a}_{3}
$$

experienced compensating changes in mass, even though the agreement between the observed differences and the predicted differences were within the surveillance limits. However, this is an unlikely situation. But, if it does occur, the weights that have changed may be identified in the manner described for the comparison between the $20 \mathrm{~g}$ and $\Sigma 20 \mathrm{~g}$ weights, as may the weights involved in any measurements where the observed difference does not agree with the predicted difference within the surveillance limits. 
In any event, if it is determined that several weights of a given set require recalibration (more than, say, three or four weights in a $100 \mathrm{~g}$ to $1 \mathrm{mg}$ set, or more in a larger set) the entire set should be recalibrated.

\subsection{Numerical Example}

The following numerical example, using difference measurement $20 \mathrm{~g}-\Sigma 20 \mathrm{~g}$, discussed above, illustrates the procedure.

The observed value of the difference:

$$
20 \mathrm{~g}-\Sigma 20 \mathrm{~g}=+0.084 \mathrm{mg}
$$

The predicted value is $+0.052 \mathrm{mg}$. The surveillance $1 \mathrm{imit}$ is $+0.028 \mathrm{mg}$. The difference between the observed value and the predicted value is:

$$
+0.084 \mathrm{mg}-0.052 \mathrm{mg}=0.032 \mathrm{mg}
$$

This difference exceeds the survelllance limits and indicates that the mass of one or more of the weights involved has changed. Three weighings were made to determine which weight, or weights, have changed. The results of these measurements are:

$$
\begin{aligned}
& \text { Observed Predicted } \\
& \text { Value of Value of Surveillance } \\
& \text { Observation } \\
& \text { Difference Difference } \\
& \text { Limit } \\
& a^{\prime} \quad 10 g-(5 g+3 g+2 g)=-0.025 \mathrm{mg}-0.057 \mathrm{mg} 0.024 \mathrm{mg} \\
& \mathrm{a}^{\prime \prime} 5 \mathrm{~g}-(3 \mathrm{~g}+2 \mathrm{~g})=-0.065 \mathrm{mg}-0.032 \mathrm{mg} 0.018 \mathrm{mg} \\
& \mathrm{a}^{\prime \prime \prime} 3 \mathrm{~g}-(2 \mathrm{~g}+1 \mathrm{~g})=+0.031 \mathrm{mg}+0.034 \mathrm{mg} \quad 0.015 \mathrm{mg}
\end{aligned}
$$

Examining these results, we find that the agreement between the observed value and the predicted value for a''' is well within the surveillance limit, thus virtually ruling out any change in the masses of the $3 \mathrm{~g}$ and $2 \mathrm{~g}$ weights. But, the observed values for $\mathrm{a}^{\prime}$ and $\mathrm{a}^{\prime \prime}$ do not agree with the predicted values within the surveillance limits. Further, the observed values for both $a^{\prime}$ and $a^{\prime \prime}$ differ from the predicted values by about the same amount, but with opposite signs.

$$
\begin{aligned}
& \text { For } a^{\prime}-0.025-(-0.057)=+0.032 \mathrm{mg} \\
& \text { For } a^{\prime}-0.065-(-0.032)=-0.033 \mathrm{mg}
\end{aligned}
$$


Had it been only for $a^{\prime}$ that the observed value did not agree with the predicted value, within the surveillance limit, it would be logical to conclude that the mass of the $10 \mathrm{~g}$ weight had changed. But, for both $\mathrm{a}^{\prime}$ and $\mathrm{a}^{\prime \prime}$, the observed values of the differences do not agree with the predicted values by about the same amount, numerically, though with opposite signs. Therefore, the conclusion is that the mass of the $5 \mathrm{~g}$ weight has changed because it is involved in both $a^{\prime}$ and $a^{\prime \prime}$, while the $10 \mathrm{~g}$ weight is involved only in $\mathrm{a}^{\prime}$. Further, the $5 \mathrm{~g}$ weight is in opposed positions in the two equations.

\section{BUOYANCY CORRECTIONS}

Buoyancy corrections are used to account for the difference in the buoyant effect of the air on weights of differing densities [5]. In some instances it will be necessary to apply buoyancy corrections to the measured differences between weights in surveillance tests because the buoyant effect on the weights may mask: real changes in their masses, or apparent changes in mass may be indicated when there is no change. This is true whether the computations of the results are made on the true mass or the apparent mass basis. In general, the buoyancy corrections computed on the true mass basis are numerically greater than buoyancy corrections computed on the apparent mass basis when weights having widely different densities are involved in a given comparison.

It is always good practice to compute, at least roughly, the magnitude of the correction to establish the order of magnitude with reference to the uncertainty of the surveillance test measurement [1]. If the correction is not significant, it can be ignored.

\subsection{Buoyancy Corrections Computed on True Mass Basis}

When the results of the surveillance test weighings are computed on the true mass basis, the expected differences being computed from the reported mass (true mass) values, the true mass buoyancy correction term, $\rho \Delta V$, for the measured difference may be derived from the weighing equation for the difference between two weights. 


$$
\left(M_{C}-\rho V_{C}\right) g-\left(M_{D}-\rho V_{D}\right) g=a g \quad \text { weighing equation }
$$

where: ${ }_{C}$ and $M_{D}=$ the masses of weights $C$ and $D$, respectively

$V_{C}$ and $V_{D}=$ the volumes of $C$ and $D$, respectively, from the Report of Calibration

$\rho=$ air density when weighing was made

$a=$ the indicated difference in mass units

$g$ = acceleration of gravity

The derivation of the buoyancy correction term, $\rho \Delta V$, for the true mass difference between the two masses $C$ and $D$ is :

$$
\begin{array}{ll}
{ }_{C}^{\left(M_{C}-\rho V_{C}\right) g-\left(M_{D}-\rho V_{D}\right) g=a g} & \text { weighing equation } \\
M_{C}-\rho V_{C}-M_{D}+\rho V_{D}=a & \text { dividing by } g \\
M_{C}-M_{D}=a+\rho\left(V_{C}-V_{D}\right) & \text { transposing and } \\
& \text { collecting terms } \\
M_{C}-M_{D}=a+\rho \Delta V & \begin{array}{l}
\text { substituting } \Delta V \\
\text { for }\left(V_{C}-V_{D}\right)
\end{array}
\end{array}
$$

It is better to use the form of the buoyancy correction term, $\rho\left(V_{C}-V_{D}\right)$, in equation (3) above when computing the buoyancy correction because its sign is more readily apparent. The following example illustrates this.

The measured difference, $a$, between $2 \mathrm{~g}$ and $\Sigma 2 \mathrm{~g}$ is $0.0388 \mathrm{mg}$.

\section{Weight Volume}

$2 \mathrm{~g}$

$1 \mathrm{~g} \quad 0.12820 \mathrm{~cm}^{3}$

$500 \mathrm{mg} \quad 0.03012 \mathrm{~cm}^{3}$

$300 \mathrm{mg} \quad 0.01807 \mathrm{~cm}^{3}$

$200 \mathrm{mg} \quad 0.01205 \mathrm{~cm}^{3}$

$\sum 2 \mathrm{~g}$

$$
\begin{array}{lll}
0.1884 \mathrm{~cm}^{3} \quad " \quad " \quad " & \\
\rho=1.17 \mathrm{mg} / \mathrm{cm}^{3} &
\end{array}
$$

$0.2564 \mathrm{~cm}^{3}$ from Report of Calibration 
The true mass difference:

$$
\begin{aligned}
2 g-\Sigma 2 g & =+0.0388+1.17(0.2564-0.1884) \\
& =+0.0388+0.0796=+0.1184 \mathrm{mg}
\end{aligned}
$$

If volumes are not listed on the Report of Calibration, they may be computed from:

$$
\text { Volume }=\frac{\text { Mass }}{\text { Density }}
$$

\subsection{Buoyancy Corrections Computed on Apparent Mass Basis}

When the results of the weighings are computed on the apparent mass ${ }^{1}$ basis [5], the expected differences being computed from the reported apparent mass values, the apparent mass buoyancy correction term, $\Delta \rho \Delta V$, - for the measured differences may be derived from the expression for finding the apparent mass when the true mass and the volume are known.

$$
A M_{W !}=M_{W}-\rho_{n}\left(V_{W}-V_{R}\right)
$$

where

$$
\begin{aligned}
A_{W}= & \text { apparent mass value of weight " } \mathrm{W} \text { " versus the refer- } \\
& \text { ence material (R) } \\
M_{W}= & \text { mass (true mass) of weight " } W " \\
\rho_{n}= & \text { density of normal air } \\
V_{W}= & \text { volume of weight " } W \text { " at } 20{ }^{\circ} \mathrm{C} \\
V_{R}= & \text { volume of equivalent mass of the reference material } \\
& \text { (R) at } 20{ }^{\circ} \mathrm{C}
\end{aligned}
$$

The derivation of the buoyancy correction term, $\Delta \rho \Delta V$, for the apparent mass difference between the weights $C$ and $D$ is:

$$
\begin{aligned}
& A M_{C}=M_{C}-\rho_{n}\left(V_{C}-V_{b}\right) \\
& A M_{D}=M_{D}-\rho_{n}\left(V_{D}-V_{b}\right)
\end{aligned}
$$

1 In the United States, the apparent mass is usually expressed as apparent mass versus normal brass in normal air. Normal brass is defined as brass having a density of $8.4 \mathrm{~g} / \mathrm{cm}^{3}$ at $0{ }^{\circ} \mathrm{C}$ and a coefficient of cubical expansion 0.000054 per degree $C$. lNormal air is defined as air having a density of $1.2 \mathrm{mg} / \mathrm{cm}^{3}$ at $20^{\circ} \mathrm{C}$. 


$$
\begin{aligned}
& { }_{C} M_{C}-A M_{D}=M_{C}-\rho_{n}\left(V_{C}-V_{b}\right)-M_{D}+\rho_{n}\left(V_{D}-V_{b}\right) \text { subtracting } \\
& A M_{C}-A M_{D}=M_{C}-M_{D}-\rho_{n} V_{C}+\rho_{n} V_{b}+\rho_{n} V_{D}-\rho_{n} V_{b} \\
& =a+\rho\left(v_{C}-v_{D}\right)-\rho_{n}\left(v_{C}-v_{D}\right) \\
& \text { substituting } a+\rho\left(V_{C}-V_{D}\right) \text { for }\left(M_{C}-M_{D}\right) \\
& \text { (see equation (3)) } \\
& A M_{C}-A M_{D}=a+\left(\rho-\rho_{n}\right)\left(V_{C}-V_{D}\right) \quad \text { combining terms } \\
& =a+\Delta p \Delta V \\
& \text { substituting } \Delta \rho \Delta \mathrm{V} \text { for } \\
& \left(\rho-\rho_{n}\right)\left(V_{C}-V_{D}\right)
\end{aligned}
$$

where ${ }^{A M} C$ and ${ }^{A M}=$ the apparent mass of weights $C$ and $D$

$$
\begin{aligned}
{ }_{C} \text { and } M_{D}= & \text { the masses of weights } C \text { and } D \\
V_{C} \text { and } V_{D}= & \text { the volumes of } C \text { and } D \text {, respectively, } \\
& \text { from the Report of Calibration } \\
\mathrm{V}_{\mathrm{b}}= & \text { the volume of equivalent mass of } \\
& \text { normal brass, the reference material } \\
\rho= & \text { the air density when the weighing was } \\
& \text { made } \\
\rho_{\mathrm{n}}= & \text { the density of normal air at } 20{ }^{\circ} \mathrm{C} .
\end{aligned}
$$

It is better to use the form in equation (10) above when computing

\begin{tabular}{|c|c|c|c|}
\hline 11 & 11 & 11 & 11 \\
\hline 11 & 11 & 11 & 11 \\
\hline 11 & $"$ & $\|$ & 11 \\
\hline 11 & " & 11 & 11 \\
\hline
\end{tabular}
the buoyancy correction term because its sign is more readily apparent.

The following example illustrates this:

The measured difference, a, between $2 g$ and $\Sigma 2 g$ is $0.0388 \mathrm{mg}$.

Weight

$2 \mathrm{~g}$

$1 \mathrm{~g} \quad 0.12820 \mathrm{~cm}^{3}$

$500 \mathrm{mg} \quad 0.03012 \mathrm{~cm}^{3}$

$300 \mathrm{mg} \quad 0.01807 \mathrm{~cm}^{3}$

$200 \mathrm{mg} \quad 0.01205 \mathrm{~cm}^{3}$

L:2 $\mathrm{g}$

$\rho=1.17 \mathrm{mg} / \mathrm{cm}^{3}$

$\rho_{\mathrm{n}}=1.20 \mathrm{mg} / \mathrm{cm}^{3}$
$0.2564 \mathrm{~cm}^{3}$ from Report of Calibration

$0.1884 \mathrm{~cm}^{3}$ 
The apparent mass difference

$$
\begin{aligned}
2 g-\Sigma 2 g & =+0.0388+(1.17-1.20)(0.2564-0.1884) \\
& =+0.0388+(-0.03)(0.0680) \\
& =+0.0388-0.0020 \\
& =+0.0368 \mathrm{mg}
\end{aligned}
$$

\subsection{Application of Buoyancy Correction}

The buoyancy correction terms derived above are correct when the mass difference and the volume difference of the weights are taken in the same direction. That is, if the difference between the masses of weights $C$ and $D$ is taken as ${ }^{M_{C}}-{ }^{M} D$ then their volume difference must be taken as $V_{C}-V_{D}$ or the buoyancy correction will have the wrong sign.

If, when assigning a mass value to one of the two weights being compared with each other, the other weight being used as the standard, a buoyancy correction is used, it is essential that the correct sign be used for the buoyancy correction term.

\subsubsection{Buoyancy Correction Application for True Mass}

Consider the relationship

$$
C-D=a+\rho\left(V_{C}-V_{D}\right)
$$

If $D$ is the standard then

$$
C=a+\rho\left(V_{C}-V_{D}\right)+D
$$

substituting for $a, \rho, V_{C}$, and $V_{D}$ and $D$ their values, we get the true nass value of $C$, provided the true mass value of $D$ was used.

If $C$, the first weight in the difference, $C-D$, is the standard (this is the situation in many weighing designs) then,

and

$$
-D=a+\rho\left(V_{C}-V_{D}\right)-C
$$

$$
D=-a-\rho\left(V_{C}-V_{D}\right)+C
$$


Substituting for $a, \rho, V_{C}, V_{D}$ and $C$ their values, we get the true mass value of $D$, provided the true mass value of $C$ was used.

Note that the sign of the buoyancy correction term in (3) above is minus. This application is illustrated on the computation sheet for the $3-1$ 's weighing design.

\subsubsection{Buoyancy Correction Application for Apparent Mass}

Consider the relationship

$$
C-D=a+\left(\rho-\rho_{n}\right)\left(V_{C}-V_{D}\right)
$$

If $\mathrm{D}$ is the standard, then

$$
C=a+\left(\rho-\rho_{n}\right)\left(V_{C}-V_{D}\right)+D
$$

Substituting for $a, \rho, \rho_{n}, V_{C}, V_{D}$, and $D$ their values, we get the apparent mass value of $C$, provided the apparent mass value of $D$ was used.

If $C$, the first weight in the difference, $C-D$, is the standard (this is the situation in many weighing designs) then,

$$
-D=a+\left(\rho-\rho_{n}\right)\left(V_{C}-V_{D}\right)-C
$$

and

$$
D=-a-\left(\rho-\rho_{n}\right)\left(V_{C}-V_{D}\right)+C
$$

Substituting for $a, \rho, \rho_{n}, V_{C}, V_{D}$ and $C$ their values, we get the apparent mass value of $D$, provided the apparent mass value of $C$ was used.

Note that the sign of the buoyancy correction term in (6) above is minus. This application is illustrated on the computation sheets for the $3-1$ 's weighing design as used in the example for the Type II surveillance test. (see appendix 2). 


\section{RECORDS}

Records are an essential part of any measurement program. In a surveillance test program, adequate records are necessary to document the continuing validity of the reported mass values and to realize the full value of the program. Such records may be simple, or elaborate, as long as they contain the information needed to document the claimed validity of the mass values. A notebook or card file should be maintained containing a description of the test system. This should include a statement of the procedures, a list of standards (if any) and weighing instruments, test intervals, and a tabulation of the accumulated results of tests. The records should also include the identity of the weights, the expected, or predicted, values of the differences measured as computed from the reported values, and the surveillance limits. The calibration report should be an integral part of the records. In addition, where the Type II Surveillance Test is used, the estimate of the standard deviation should be compared for each 3-1's series, compared with the long term estimate of the standard deviation and recorded. This information, combined with the original data sheets, forms an adequate record. A large operation may require a nore elaborate record keeping system.

Control charts [3] similar to the one illustrated on page 18 are a useful addition to the surveillance test records. Control charts show more readily than tabulations whether a trend in the values of the differences being measured is developing. Such trends, when detected, can signal the need for recalibration before the values of the mass standards become invalid.

\section{SURVEILLANCE TEST INTERVAL}

The purpose of surveillance test procedures is to assure continuing validity of the values contained in the calibration report and to prevent, or at least minimize, the possibility of using the weights as standards when their reported values are no longer valid. But, when and how frequently should the surveillance test procedures be used in order to achieve this goal? Recause of the many variables affecting the stability of the weights, such as the type of weights, the use to which the weights are put, the care they receive, etc., a categorical answer covering all situations cannot be given. 


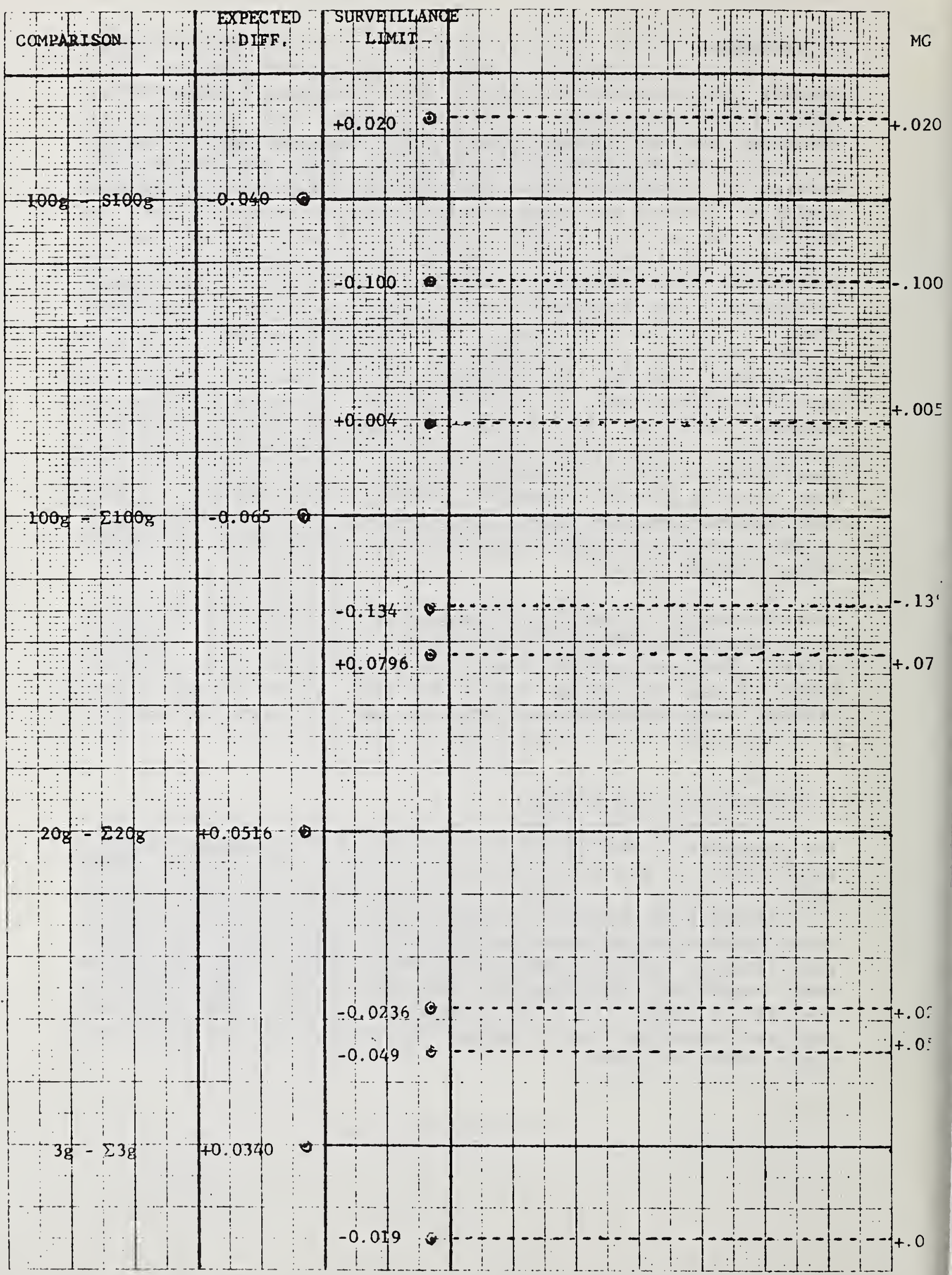


The following suggestions, where they are applicable, may serve as general guide lines for the use of surveillance tests and the interval between surveillance tests.

1. Immediately upon the receipt of a newly calibrated set of weights, comparisons should be made to verify the values reported.

2. If this is a set for which no history exists, the comparisons should be repeated monthly, or bimonthly until the degree of stability of the weights has been demonstrated.

3. Where sufficient information about a set of weights has been developed to predict their performance with some degree of certainty, this information may be used in determining the interval between surveillance tests.

4. If there has been an accident with the weights, such as dropping them on the floor, at least the weights involved in the accident should be given a surveillance test before being used as standards to be sure that their reported values are still valid.

5. If a facility performs a large number of calibrations, its procedures should provide "built-in" checks on standards and if the standards checked on are part of the set in question, the information developed from these "built-in" checks can be used to determine when a surveillance test is needed.

6. Where the number of calibrations performed is small, the standards may be given a surveillance test just prior to using the standards in the calibration of other weights. 
[1] Pontius, P. E., Measurement Philosophy of the Pilot Program for Mass Calibration, Nat. Bur. Stand. (U.S.), Tech. Note 288,39 pages (1968).

[2] Almer, H. E., Method of Calibrating Weights for Piston Gages, Nat. Bur. Stand. (U.S.), Tech. Note 577, 49 pages (1971).

[3] Pontius, P. E., Cameron, J. M., Realistic Uncertainties and The Mass Measurement Process, Nat. Bur. Stand. (U.S.), Monogr. 103, 17 pages (1967).

[4] Youden, W. J., Statistical Methods for Chemists, John Wiley \& Sons, New York (1541).

[5] Nat. Bur. Stand. (U.S.), Handbook 77, Precision Measurement and Calibration, Volume III, Optics, Metrology and Radiation, Circular 3, pp. $671 / 53$ to 683/65. This handbook is available for reference in. most Government Depository Libraries throughout the United States. 
The weighing design used in a given surveillance test depends on the range of the set and ratio of the weights in the set to each other. Some suggested weighing designs for weight sets having 5 , $3,2,1 ; 5,2,2,1$ and $5,2,1,1, \Sigma 1$ ratios are shown for various ranges. Other designs may be developed by using the principles outlines in section 2 for situations where the suggested weighing designs do not apply. The surveillance test weighing designs are shown with metric units of mass. But with a given design, customary units of mass can be substituted for the metric units, provided the ratios of the weights to each other are the same in both systems. 
Weighing Designs for Type I Surveillance Test

Design 1

Set - Range: $1 \mathrm{~kg}$ to $1 \mathrm{mg}$

Ratio $5,3,2,1$

$$
\begin{aligned}
& 1 \mathrm{~kg}-\mathrm{s} 1 \mathrm{~kg}=\mathrm{a}_{1} * \\
& \mathrm{~S} 1 \mathrm{~kg}=\text { Standard } 1 \mathrm{~kg} \\
& 1 \mathrm{~kg}-\sum 1 \mathrm{~kg}=\mathrm{a}_{2} \\
& \Sigma 1 \mathrm{~kg}=500 \mathrm{~g}+300 \mathrm{~g}+200 \mathrm{~g} \\
& 200 g-\sum 200 g=a_{3} \\
& \Sigma 200 \mathrm{~g}=100 \mathrm{~g}+50 \mathrm{~g}+30 \mathrm{~g}+20 \mathrm{~g} \\
& 20 \mathrm{~g}-\sum 20 \mathrm{~g}=\mathrm{a}_{4} \\
& \sum 20 g=10 g+5 g+3 g+2 g \\
& 2 \mathrm{~g}-\Sigma 2 \mathrm{~g}=\mathrm{a}_{5} \\
& \sum 2 \mathrm{~g}=1 \mathrm{~g}+500 \mathrm{mg}+300 \mathrm{mg}+200 \mathrm{mg} \\
& 200 \mathrm{mg}-\Sigma 200 \mathrm{mg}=\mathrm{a}_{6} \\
& \sum 200 \mathrm{mg}=100 \mathrm{mg}+50 \mathrm{mg}+30 \mathrm{mg}+20 \mathrm{mg} \\
& 20 \mathrm{mg}-\sum 20 \mathrm{mg}=\mathrm{a}_{7} \\
& \sum 20 m g=10 m g+5 m g+3 m g+2 m g \\
& 3 \mathrm{mg}-\Sigma 3 \mathrm{mg}=\mathrm{a}_{8} \\
& \sum 3 \mathrm{mg}=2 \mathrm{mg}+1 \mathrm{mg}
\end{aligned}
$$

* If a known $1 \mathrm{~kg}$ weight suitable for use as a standard is not available, this " $a$ " is omitted and $1 \mathrm{~kg}$ - $\Sigma 1 \mathrm{~kg}$ becomes the first "a", $200 \mathrm{~g}-\sum 200 \mathrm{~g}=\mathrm{a}_{2}, 20 \mathrm{~g}-\sum 20 \mathrm{~g}=\mathrm{a}_{3}$, etc. 
Design 2

Set - Range: $100 \mathrm{~g}$ to $1 \mathrm{mg}$

Ratio: $5,3,2,1$

$$
\begin{aligned}
100 \mathrm{~g}-\mathrm{S} 100 \mathrm{~g} & =\mathrm{a}_{1} * \\
5100 \mathrm{~g} & =\text { Standard } 100 \mathrm{~g} \text { Weight } \\
100 \mathrm{~g}-\Sigma 100 \mathrm{~g} & =\mathrm{a}_{2} \\
\Sigma 100 \mathrm{~g} & =50 \mathrm{~g}+30 \mathrm{~g}+20 \mathrm{~g} \\
20 \mathrm{~g}-\Sigma 20 \mathrm{~g} & =\mathrm{a}_{3} \\
\Sigma 20 \mathrm{~g} & =10 \mathrm{~g}+5 \mathrm{~g}+3 \mathrm{~g}+2 \mathrm{~g} \\
2 \mathrm{~g}-\Sigma 2 \mathrm{~g}= & \mathrm{a}_{4} \\
\Sigma 2 \mathrm{~g}= & 1 \mathrm{~g}+500 \mathrm{mg}+300 \mathrm{mg}+200 \mathrm{mg} \\
200 \mathrm{mg}-\Sigma 200 \mathrm{mg} & =\mathrm{a}_{5} \\
\Sigma 200 \mathrm{mg} & =100 \mathrm{mg}+50 \mathrm{mg}+30 \mathrm{mg}+20 \mathrm{mg} \\
20 \mathrm{mg}-\Sigma 20 \mathrm{mg} & =\mathrm{a}_{6} \\
\Sigma 20 \mathrm{mg} & =10 \mathrm{mg}+5 \mathrm{mg}+3 \mathrm{mg}+2 \mathrm{mg} \\
3 \mathrm{mg}-\Sigma 3 \mathrm{mg} & =\mathrm{a}_{7} \\
3 \mathrm{mg} & =2 \mathrm{mg}+1 \mathrm{mg}
\end{aligned}
$$

For sets in which the smallest weight is $1 \mathrm{~g}$, the last "a" would be:

$$
\begin{aligned}
3 g-\Sigma 3 g & =a \\
\sum 3 g & =2 g+1 g
\end{aligned}
$$

* If a known $100 \mathrm{~g}$ weight suitable for use as a standard is not available, this "a" is omitted and $100 \mathrm{~g}-\sum 100 \mathrm{~g}$ becomes the first "a", $20 \mathrm{~g}-\sum 20 \mathrm{~g}=\mathrm{a}_{2}$, etc. 
Design 3

Set - Range: $1 \mathrm{~kg}$ to $1 \mathrm{mg} \quad$ Ratio: $5,2,2,1$

$$
\begin{aligned}
1 \mathrm{~kg}-\mathrm{S} 1 \mathrm{~kg} & =a_{1} * \\
\text { S1kg } & =\text { Standard } 1 \mathrm{~kg} \text { Weight } \\
1 \mathrm{~kg}-\Sigma 1 \mathrm{~kg}= & a_{2} \\
\Sigma 1 \mathrm{~kg} & =500 \mathrm{~g}+200 \mathrm{~g}_{1}+200 \mathrm{~g}_{2}+100 \mathrm{~g} \\
100 \mathrm{~g}-\Sigma 100 \mathrm{~g} & =\mathrm{a}_{3} \\
\Sigma 100 \mathrm{~g} & =50 \mathrm{~g}+20 \mathrm{~g}_{1}+20 \mathrm{~g}_{2}+10 \mathrm{~g} \\
10 \mathrm{~g}-\Sigma 10 \mathrm{~g} & =\mathrm{a}_{4} \\
\Sigma 10 \mathrm{~g} & =5 \mathrm{~g}+2 \mathrm{~g}_{1}+2 \mathrm{~g}_{2}+1 \mathrm{~g} \\
1 \mathrm{~g}-\Sigma 1 \mathrm{~g}= & \mathrm{a}_{5} \\
\Sigma 1 \mathrm{~g} & =500 \mathrm{mg}+20 \mathrm{cmg}_{1}+200 \mathrm{mg}_{2}+100 \mathrm{mg} \\
100 \mathrm{mg}- & \Sigma 100 \mathrm{mg}=\mathrm{a}_{6} \\
\Sigma 100 \mathrm{mg} & =50 \mathrm{mg}+20 \mathrm{mg}_{1}+20 \mathrm{mg}_{2}+10 \mathrm{mg} \\
10 \mathrm{mg}- & \Sigma 10 \mathrm{mg}=\mathrm{a}_{7} \\
\Sigma 10 \mathrm{mg} & =5 \mathrm{mg}+2 \mathrm{mg}_{1}+2 \mathrm{mg}_{2}+1 \mathrm{mg}
\end{aligned}
$$

* If a known $1 \mathrm{~kg}$ weight suitable for use as a standard is not available, this " $\mathrm{a}$ " is omitted and $1 \mathrm{~kg}$ - $\sum 1 \mathrm{~kg}$ becomes the first "a", and $100 \mathrm{~g}-\Sigma 100 \mathrm{~g}=\mathrm{a}_{2}, 10 \mathrm{~g}-\Sigma 10 \mathrm{~g}=\mathrm{a}_{3}$, etc. 
Design 4

$$
\begin{aligned}
& \text { Set - Range: 100g - 1mg Ratio: 5, 2, 2, } 1 \\
& 100 \mathrm{~g}-\mathrm{S} 100 \mathrm{~g}=\mathrm{a}_{1} * \\
& \mathrm{~S} 100 \mathrm{~g}=\text { Standard } 100 \mathrm{~g} \text { Weight } \\
& 100 \mathrm{~g}-\sum 100 \mathrm{~g}=\mathrm{a}_{2} \\
& \Sigma 100 \mathrm{~g}=50 \mathrm{~g}+20 \mathrm{~g}_{1}+20 \mathrm{~g}_{2}+10 \mathrm{~g} \\
& 10 \mathrm{~g}-\Sigma 10 \mathrm{~g}=\mathrm{a}_{3} \\
& \Sigma 10 \mathrm{~g}=5 \mathrm{~g}+2 \mathrm{~g}_{1}+2 \mathrm{~g}_{2}+1 \mathrm{~g} \\
& 1 \mathrm{~g}-\Sigma 1 \mathrm{~g}=\mathrm{a}_{4} \\
& \Sigma 1 \mathrm{~g}=500 \mathrm{mg}+200 \mathrm{mg} \mathrm{g}_{1}+200 \mathrm{mg}_{2}+100 \mathrm{mg} \\
& 100 \mathrm{mg}-\Sigma 100 \mathrm{mg}=\mathrm{a}_{5} \\
& \sum 100 \mathrm{mg}=50 \mathrm{mg}+20 \mathrm{mg} \mathrm{g}_{1}+20 \mathrm{mg}_{2}+10 \mathrm{mg} \\
& 10 \mathrm{mg}-\Sigma 10 \mathrm{mg}=\mathrm{a}_{6} \\
& \sum 10 \mathrm{mg}=5 \mathrm{mg}+2 \mathrm{mg}_{1}+2 \mathrm{mg} \mathrm{g}_{2}+1 \mathrm{mg}
\end{aligned}
$$

For the set in which the smallest weight is $1 \mathrm{~g}$, the last " $\mathrm{a}$ " would be:

$$
\begin{aligned}
5 g-\Sigma 5 g & =a \\
\Sigma 5 g & =2 g_{1}+2 g_{2}+1 g
\end{aligned}
$$

* If a known $100 \mathrm{~g}$ weight suitable for use as a standard is not available, this "a" is omitted and $100 \mathrm{~g}-\sum 100 \mathrm{~g}$ becomes the first "a", and $10 \mathrm{~g}-\sum 10 \mathrm{~g}=\mathrm{a}_{2}$, etc. 
Design 5

$$
\begin{aligned}
& \text { Set - Range: } 30 \mathrm{~kg} \text { - ligg Ratio: 5, 3, 2, } 1 \\
& 30 \mathrm{~kg}-\Sigma 30 \mathrm{~kg}=\mathrm{a}_{1} \\
& \sum 30 \mathrm{~kg}=20 \mathrm{~kg}+10 \mathrm{~kg} \\
& 10 \mathrm{~kg}-\sum 10 \mathrm{~kg}=\mathrm{a}_{2} \\
& \Sigma 10 \mathrm{~kg}=5 \mathrm{~kg}+3 \mathrm{~kg}+2 \mathrm{~kg} \\
& 2 \mathrm{~kg}-\Sigma 2 \mathrm{~kg}=\mathrm{a}_{3} \\
& \sum 2 \mathrm{~kg}=1 \mathrm{~kg}_{1}+1 \mathrm{~kg}_{2} \\
& 1 \mathrm{~kg} \mathrm{l}-\sum 1 \mathrm{~kg}=\mathrm{a}_{4} \\
& \sum 1 \mathrm{~kg}=500 \mathrm{~g}+300 \mathrm{~g}+200 \mathrm{~g} \\
& 200 \mathrm{~g}-\Sigma 200 \mathrm{~g}=\mathrm{a}_{5} \\
& \sum 200 \mathrm{~g}=100 \mathrm{~g}+50 \mathrm{~g}+30 \mathrm{~g}+20 \mathrm{~g} \\
& 20 \mathrm{~g}-\Sigma 20 \mathrm{~g}=\mathrm{a}_{6} \\
& \Sigma 20 g=10 g+5 g+3 g+2 g \\
& 2 \mathrm{~g}-\Sigma 2 \mathrm{~g}=\mathrm{a}_{7} \\
& \Sigma 2 g=1 g+500 m g+300 m g+200 m g \\
& 200 \mathrm{mg}-\Sigma 200 \mathrm{mg}=\mathrm{a}_{8} \\
& \Sigma 200 \mathrm{mg}=100 \mathrm{mg}+50 \mathrm{mg}+30 \mathrm{mg}+20 \mathrm{mg} \\
& 20 \mathrm{mg}-\Sigma 20 \mathrm{mg}=\mathrm{a}_{\mathrm{g}} \\
& \Sigma 20 \mathrm{mg}=10 \mathrm{mg}+5 \mathrm{mg}+3 \mathrm{mg}+2 \mathrm{mg} \\
& 2 m g-\Sigma 2 m g=a_{10} \\
& \sum 2 \mathrm{mg}=1 \mathrm{mg} 1-1 \mathrm{mg} g_{2}
\end{aligned}
$$


Weighing Designs for Type I Surveillance Tests

Design 6

Set - Range: $100 \mathrm{~g}$ - $1 \mathrm{mg}$

Ratio: 5, 2, 1, 1, $\sum 1$

$$
\begin{aligned}
100 \mathrm{~g}-\mathrm{S} 100 \mathrm{~g} & =\mathrm{a}_{1} * \\
\mathrm{~S} 100 \mathrm{~g} & =\text { Standard } 100 \mathrm{~g} \text { weight } \\
100 \mathrm{~g}-\Sigma 100 \mathrm{~g} & =\mathrm{a}_{2} \\
\Sigma 100 \mathrm{~g} & =50 \mathrm{~g}+20 \mathrm{~g}+10 \mathrm{~g}_{1}+10 \mathrm{~g}_{2}+\Sigma 10 \mathrm{~g} \\
10 \mathrm{~g}_{1}-\Sigma 10 \mathrm{~g} & =\mathrm{a}_{3} \\
1 \mathrm{~g}_{1}-\Sigma 1 \mathrm{~g} & =\mathrm{a}_{4} \\
\Sigma 1 \mathrm{~g} & =500 \mathrm{mg}+200 \mathrm{mg}+100 \mathrm{mg}+100 \mathrm{mg}_{2}+\Sigma 100 \mathrm{mg} \\
100 \mathrm{mg}-\Sigma 100 \mathrm{mg} & =\mathrm{a}_{5} \\
\Sigma 100 \mathrm{mg} & =50 \mathrm{mg}+20 \mathrm{mg}+10 \mathrm{mg}_{1}+10 \mathrm{mg}_{2}+\Sigma 10 \mathrm{mg} \\
10 \mathrm{mg}-\Sigma 10 \mathrm{mg} & =\mathrm{a}_{6} \\
\Sigma 10 \mathrm{mg} & =5 \mathrm{mg}+2 \mathrm{mg}+1 \mathrm{mg}_{1}+1 \mathrm{mg}_{2}+1 \mathrm{mg}_{3}
\end{aligned}
$$

When comparing the unit of weight of a given decade of weights with summation of smaller veights from a weight set in which the ratio of the weights to each other $5,2,1,1,1$, it is necessary to include all of the set's weights smaller than the unit weight to which summation is being compared. For example: in the comparison $100 \mathrm{~g}-\Sigma 100 \mathrm{~g}$, the $\sum 100 \mathrm{~g}$ includes all of the weights in the set smaller than $100 \mathrm{~g}$; and in the comparison $10 \mathrm{~g}$ $\sum 10 \mathrm{~g}$ the $\Sigma 10 \mathrm{~g}$ includes all of the weights smaller than $10 \mathrm{~g}$ and so on.

* If a known $100 \mathrm{~g}$ weight suitable for use as a standard is not available, this "a" is omitted and $100 \mathrm{~g}-\Sigma 100 \mathrm{~g}$ becomes the first "a" and $10 \mathrm{~g}-\Sigma 10 \mathrm{~g}=\mathrm{a}_{2}$, etc. 
Weighing Designs for Type II Surveillance Tests

Design 7

Set - Range: $1 \mathrm{~kg}$ to $1 \mathrm{mg}$

Ratio: $5,3,2,1$

Series 1

$$
\begin{aligned}
& \text { S1kg - } 1 \mathrm{~kg} \quad=\mathrm{a}_{1}{ }^{*} \\
& \mathrm{~S} 1 \mathrm{~kg} \quad-\Sigma 1 \mathrm{~kg}=\mathrm{a}_{2} \\
& 1 \mathrm{~kg}-\Sigma 1 \mathrm{~kg}=\mathrm{a}_{3} \\
& \mathrm{~S} 1 \mathrm{~kg}=\text { Standard } 1 \mathrm{~kg} \\
& \Sigma 1 \mathrm{~kg}=500 \mathrm{~g}+300 \mathrm{~g}+200 \mathrm{~g}
\end{aligned}
$$

Series 2

$$
\begin{gathered}
300 g-\Sigma 300 g_{1}=a_{1} \\
300 g-\Sigma 300 g_{2}=a_{2} \\
\Sigma 300 g_{1}-\Sigma 300 g_{2}=a_{3} \\
\Sigma 300 g_{1}=200 g+100 g \\
\Sigma 300 g_{2}=200 g+50 g+30 g+20 g
\end{gathered}
$$

Series 3

$$
\begin{gathered}
30 \mathrm{~g}-\Sigma 30 \mathrm{~g}_{1}=\mathrm{a}_{1} \\
30 \mathrm{~g}-\Sigma 30 \mathrm{~g}_{2}=\mathrm{a}_{2} \\
\Sigma 30 \mathrm{~g}_{1}-\Sigma 30 \mathrm{~g}_{2}=\mathrm{a}_{3} \\
\Sigma 30 \mathrm{~g}_{1}=20 \mathrm{~g}+10 \mathrm{~g} \\
\Sigma 30 \mathrm{~g}_{2}=20 \mathrm{~g}+5 \mathrm{~g}+3 \mathrm{~g}+2 \mathrm{~g}
\end{gathered}
$$

Series 4

$$
\begin{gathered}
3 g-\Sigma 3 g_{1}=a_{1} \\
3 g-\Sigma 3 g_{2}=a_{2} \\
\Sigma 3 g_{1}-\Sigma 3 g_{2}=a_{3} \\
\Sigma 3 g_{1}=2 g+1 g \\
\Sigma 3 g_{2}=2 g+500 m g+300 m g+200 m g
\end{gathered}
$$


Series 5

$$
\begin{aligned}
& 300 \mathrm{mg}-\sum 300 \mathrm{mg} \mathrm{g}_{1} \quad=\mathrm{a}_{1} \\
& 300 \mathrm{mg}-\sum 300 \mathrm{mg}_{2}=\mathrm{a}_{2} \\
& \sum 300 m g_{1}-\sum 300 m g_{2}=a_{3} \\
& \left.\sum 300 \mathrm{mg}\right]_{1}=200 \mathrm{mg}+100 \mathrm{mg} \\
& \sum 300 \mathrm{mg}_{2}=200 \mathrm{mg}+50 \mathrm{mg}+30 \mathrm{mg}+20 \mathrm{mg}
\end{aligned}
$$

Series 6

$$
\begin{aligned}
& 30 \mathrm{mg}-\Sigma 30 \mathrm{mg} g_{1}=\mathrm{a}_{1} \\
& 30 \mathrm{mg} \quad-\Sigma 30 \mathrm{mg}_{2}=\mathrm{a}_{2} \\
& \sum 30 \mathrm{mg} g_{1}-\Sigma 30 \mathrm{mg}_{2}=\mathrm{a}_{3} \\
& \sum 30 \mathrm{mg}_{1}=20 \mathrm{mg}+10 \mathrm{mg} \\
& \sum 30 \mathrm{mg}_{2}=20 \mathrm{mg}+5 \mathrm{mg}+3 \mathrm{mg}+2 \mathrm{mg}
\end{aligned}
$$

Series 7

$$
\begin{aligned}
& 3 m g-\Sigma 3 m g_{1}=a_{1} \\
& 3 m g-\Sigma 3 m g_{2}=a_{2} \\
& \Sigma 3 m g_{1}-\Sigma 3 m g_{2}=a_{3} \\
& \Sigma 3 m g_{1}=2 m g+1 m g_{1} \\
& \Sigma 3 m g_{2}=2 m g+1 m g_{2} * *
\end{aligned}
$$

* If a known $1 \mathrm{~kg}$ weight, suitable for use as a standard is not available, any $1 \mathrm{~kg}$ or $\Sigma 1 \mathrm{~kg}$ may be used to fill the series. Then the $1 \mathrm{~kg}$ of the set is used as the standard and the first series of measurements is:

$$
\begin{aligned}
& 1 \mathrm{~kg}-1 \mathrm{~kg}^{\prime}=\mathrm{a}_{1} \\
& 1 \mathrm{~kg}-\Sigma 1 \mathrm{~kg}=\mathrm{a}_{2} \\
& 1 \mathrm{~kg}^{\prime}-\Sigma 1 \mathrm{~kg}=\mathrm{a}_{3}
\end{aligned}
$$

where $1 \mathrm{~kg}^{\prime}$ is either the $1 \mathrm{~kg}$ weight or the $\Sigma 1 \mathrm{~kg}$ used to complete the series.

** The $1 \mathrm{mg}_{2}$ is an extra $1 \mathrm{mg}$ weight used to fill the last series. 
Design 8

Series - Range: $100 \mathrm{~g}$ to $1 \mathrm{mg}$

Ratio: 5, 3, 2, 1

Series 1

$$
\begin{aligned}
& S 100 g-100 g=a_{1} * \\
& S 100 g-\Sigma 100 g=a_{2} \\
& 100 g-\Sigma 100 g=a_{3} \\
& \Sigma 100 g=50 g+30 g+20 g
\end{aligned}
$$

Series 2

$$
\begin{aligned}
& 30 g-\Sigma 30 g_{1}=a_{1} \\
& 30 g-\Sigma 30 g_{2}=a_{2} \\
& \Sigma 30 g_{1}-\Sigma 30 g_{2}=a_{3} \\
& \Sigma 30 g_{1}=20 g+10 g \\
& \Sigma 30 g_{2}=20 g+5 g+3 g+2 g
\end{aligned}
$$

Series 3

$$
\begin{aligned}
3 g & -\Sigma 3 g_{1}=a_{1} \\
3 g & -\Sigma 3 g_{2}=a_{2} \\
\Sigma 3 g_{1} & -\Sigma 3 g_{2}=a_{3} \\
\Sigma 3 g_{1} & =2 g+1 g \\
\Sigma 3 g_{2} & =2 g+500 m g+300 m g+200 m g
\end{aligned}
$$

Series 4

$$
\begin{aligned}
& 300 \mathrm{mg}-\Sigma 300 \mathrm{mg} g_{1}=a_{1} \\
& 300 \mathrm{mg}-\Sigma 300 \mathrm{mg}_{2}=a_{2} \\
& \Sigma 300 m g_{1}-\Sigma 300 \mathrm{mg}_{2}=a_{3} \\
& \Sigma 300 \mathrm{mg}_{1}=200 \mathrm{mg}+100 \mathrm{mg} \\
& \Sigma 300 \mathrm{mg}_{2}=200 \mathrm{mg}+50 \mathrm{mg}+30 \mathrm{mg}+20 \mathrm{mg}
\end{aligned}
$$


Series 5

$$
\begin{aligned}
& 30 m g-\Sigma 30 m g_{1}=a_{1} \\
& 30 m g-\Sigma 30 m g_{2}=a_{2} \\
& \Sigma 30 m g_{1}-\sum 30 m g_{2}=a_{3} \\
& \Sigma 30 m g_{1}=20 m g+10 m g \\
& \sum 30 m_{2}=20 m g+5 m g+3 m g+2 m g
\end{aligned}
$$

Series; 6

$$
\begin{aligned}
& 3 m g-\sum 3 m g_{1}=a_{1} \\
& 3 m g-\sum 3 m g_{2}=a_{2} \\
& \sum 3 m g_{1}-\sum 3 m g_{2}=a_{3} \\
& \sum 3 m g_{1}=2 m g+1 m g_{1} \\
& \sum 3 m g_{2}=2 m g+1 m g_{2}^{* *}
\end{aligned}
$$

* If a known $100 \mathrm{~g}$ weight suitable for use as a standard is not available, any $100 \mathrm{~g}$ weight or $\Sigma 100 \mathrm{~g}$ weight may be used to fill the first series. Then the $100 \mathrm{~g}$ of the set is used as the standard and the first series of measurement is:

$$
\begin{aligned}
& 100 \mathrm{~g}-100 \mathrm{~g}^{\prime}=\mathrm{a}_{1} \\
& 100 \mathrm{~g}-\Sigma 100 \mathrm{~g}=\mathrm{a}_{2} \\
& 100 \mathrm{~g}^{\prime}-\Sigma 100 \mathrm{~g}=\mathrm{a}_{3}
\end{aligned}
$$

where $100 \mathrm{~g}^{\prime}$ is either the $100 \mathrm{~g}$ or the $\Sigma 100 \mathrm{~g}$ used to complete the series.

** The $1 \mathrm{mg}_{2}$ is an extra $1 \mathrm{mg}$ weight used to fill the last series. 
Design 9

Set - Range: $1 \mathrm{~kg}$ to $1 \mathrm{mg}$ Ratio: 5, 2, 2, 1

Series 1

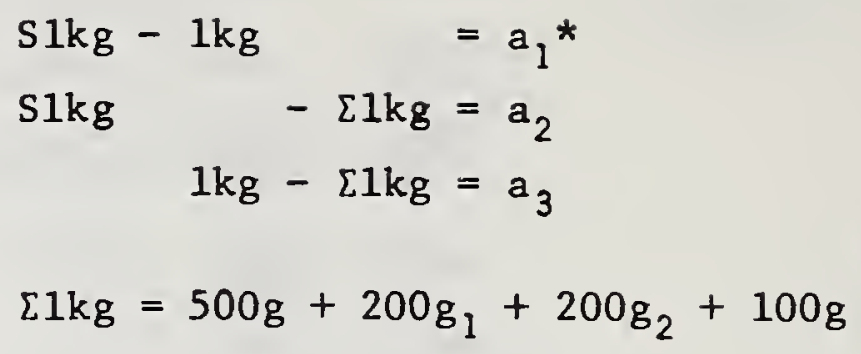

Series 2

$$
\begin{aligned}
& 200 g_{1}-200 g_{2}=a_{1} \\
& 200 g_{1}-\Sigma 200 g=a_{2} \\
& 200 g_{2}-\Sigma 200 g=a_{3} \\
& \Sigma 200 g=100 g+50 g+20 g_{1}+20 g_{2}+10 g
\end{aligned}
$$

Series 3

$$
\begin{aligned}
& 20 g_{1}-20 g_{2} \quad=a_{1} \\
& 20 g_{1}-\Sigma 20 g=a_{2} \\
& 20 g_{2}-\Sigma 20 g=a_{3} \\
& \Sigma 20 g=10 g+5 g+2 g_{1}+2 g_{2}+1 g
\end{aligned}
$$

Sertes 4

$$
\begin{aligned}
2 g_{1}-2 g_{2} & =a_{1} \\
2 g_{1}-\Sigma 2 g & =a_{2} \\
2 g_{2}-\Sigma 2 g & =a_{3} \\
\Sigma 2 g=1 g+500 m g & +200 m g_{1}+200 m g_{2}+100 m g
\end{aligned}
$$


Series 5

$$
\begin{aligned}
& 200 m g_{1}-200 m g_{2}=a_{1} \\
& 200 m g_{1}-\Sigma 200 m g=a_{2} \\
& 200 m g_{2}-\Sigma 200 m g=a_{3} \\
& \Sigma 200 m g=100 m g+50 m g+20 m g_{1}+20 m g_{2}+10 m g
\end{aligned}
$$

Series 6

$$
\begin{aligned}
& 20 \mathrm{mg}_{1}-20 m g_{2}=a_{1} \\
& 20 m g_{1}-\Sigma 20 m g=a_{2} \\
& 20 m g_{2}-\Sigma 20 m g=a_{3} \\
& \sum 20 m g=10 m g+5 m g_{1}+2 m g_{1}+2 m g_{2}+1 m g
\end{aligned}
$$

Series 7

$$
\begin{aligned}
& 2 m g_{1}-2 m g_{2}=a_{1} \\
& 2 m g_{1}-\Sigma 2 m g=a_{2} \\
& 2 m g_{2}-\Sigma 2 m g=a_{3} \\
& \Sigma 2 m g=1 m g_{1}+1 m g_{2} * *
\end{aligned}
$$

* If a known $1 \mathrm{~kg}$ weight suitable for use as a standard is not available, any $1 \mathrm{~kg}$ weight or $\Sigma 1 \mathrm{~kg}$ weight may be used to fill the series. Then the $1 \mathrm{~kg}$ of the set is used as the standard and the first series of measurements is:

$$
\begin{aligned}
& 1 \mathrm{~kg}-1 \mathrm{~kg}^{\prime}=\mathrm{a}_{1} \\
& 1 \mathrm{~kg}-\Sigma 1 \mathrm{~kg}=\mathrm{a}_{2} \\
& 1 \mathrm{~kg}^{\prime}-\Sigma 1 \mathrm{~kg}=\mathrm{a}_{3}
\end{aligned}
$$

where $1 \mathrm{~kg}^{\prime}$ is either the $1 \mathrm{~kg}$ weight or the $\Sigma 1 \mathrm{~kg}$ used to complete the series.

** The $1 \mathrm{mg}_{2}$ is an extra $1 \mathrm{mg}$ weight used to fill the 1 ast series. 
Design 10

Set - Range: $30 \mathrm{~kg}$ to $1 \mathrm{mg}$

Ratio: 5, 3, 2, 1

Series 1

$$
\begin{aligned}
& 30 \mathrm{~kg}-\Sigma 30 \mathrm{~kg}_{1}=a_{1} \\
& 30 \mathrm{~kg}-\Sigma 30 \mathrm{~kg}_{2}=a_{2} \\
& \Sigma 30 \mathrm{~kg}_{1}-\Sigma 30 \mathrm{~kg}_{2}=a_{3} \\
& \Sigma 30 \mathrm{~kg}_{1}=20 \mathrm{~kg}+10 \mathrm{~kg} \\
& \Sigma 30 \mathrm{~kg}_{2}=20 \mathrm{~kg}+5 \mathrm{~kg}+3 \mathrm{~kg}+2 \mathrm{~kg}
\end{aligned}
$$

Series 2

$$
\begin{array}{r}
3 \mathrm{~kg}-\Sigma 3 \mathrm{~kg} g_{1}=a_{1} \\
3 \mathrm{~kg}-\Sigma 3 k g_{2}=a_{2} \\
\Sigma 3 k g_{1}-\Sigma 3 k g_{2}=a_{3} \\
\Sigma 3 k g_{1}=2 \mathrm{~kg}+1 \mathrm{~kg} . \\
\Sigma 3 \mathrm{~kg}_{2}=2 \mathrm{~kg}+1 \mathrm{~kg} .
\end{array}
$$

Series 3

$$
\begin{aligned}
& 1 \mathrm{~kg} .-1 \mathrm{~kg} . .=a_{1} \\
& 1 \mathrm{~kg} .-\Sigma 1 \mathrm{~kg}=a_{2} \\
& 1 \mathrm{~kg} . .-\Sigma 1 \mathrm{~kg}=a_{3} \\
& \Sigma 1 \mathrm{~kg}=500 \mathrm{~g}+300 \mathrm{~g}+200 \mathrm{~g}
\end{aligned}
$$

Series 4

$$
\begin{aligned}
& 300 \mathrm{~g}-\Sigma 300 \mathrm{~g}_{1}=\mathrm{a}_{1} \\
& 300 \mathrm{~g}-\Sigma 300 \mathrm{~g}_{2}=\mathrm{a}_{2} \\
& \Sigma 300 \mathrm{~g}_{1}-\Sigma 300 \mathrm{~g}_{2}=\mathrm{a}_{3} \\
& \Sigma 300 \mathrm{~g}_{1}=200 \mathrm{~g}+100 \mathrm{~g} \\
& \Sigma 300 \mathrm{~g}_{2}=200 \mathrm{~g}+50 \mathrm{~g}+30 \mathrm{~g}+20 \mathrm{~g}
\end{aligned}
$$


Series 5

$$
\begin{aligned}
& 30 g-\Sigma 30 g_{1}=a_{1} \\
& 30 g-\Sigma 30 g_{2}=a_{2} \\
& \Sigma 30 g_{1}-\Sigma 30 g_{2}=a_{3} \\
& \Sigma 30 g_{1}=20 g+10 g \\
& \Sigma 30 g_{2}=20 g+5 g+3 g+2 g
\end{aligned}
$$

Series 6

$$
\begin{aligned}
& 3 g-\Sigma 3 g_{1}=a_{1} \\
& 3 g-\Sigma 3 g_{2}=a_{2} \\
& \Sigma 3 g_{1}-\Sigma 3 g_{2}=a_{3} \\
& \sum 3 g_{1}=2 g+1 g \\
& \sum 3 g_{2}=2 g+500 m g+300 m g+200 m g
\end{aligned}
$$

Series 7

$$
\begin{aligned}
& 300 m g-\Sigma 300 m g_{1}=a_{1} \\
& 300 m g-\Sigma 300 m g_{2}=a_{2} \\
& \Sigma 300 m g_{1}-\Sigma 300 m g_{2}=a_{3} \\
& \Sigma 300 m g_{1}=200 m g+100 m g \\
& \Sigma 300 m g_{2}=200 m g+50 m g+30 m g+20 m g
\end{aligned}
$$

Series 8

$$
\begin{aligned}
& 30 m g-\Sigma 30 m g_{1}=a_{1} \\
& 30 m g-\Sigma 30 m g_{2}=a_{2} \\
& \Sigma 30 m g_{1}-\Sigma 30 m g_{2}=a_{3} \\
& \Sigma 30 m g_{1}=20 m g+10 m g \\
& \Sigma 30 m g_{2}=20 m g+5 m g+3 m g+2 m g
\end{aligned}
$$

Series 9

$$
\begin{aligned}
& 3 m g-\Sigma 3 m g_{1}=a_{1} \\
& 3 m g-\Sigma 3 m g_{2}=a_{2} \\
& \Sigma 3 m g_{1}-\Sigma 3 n g_{2}=a_{3} \\
& \Sigma 3 m g_{1}=2 m g+1 m g_{1} \\
& \Sigma 3 m g_{2}=2 m g+1 m g_{2}
\end{aligned}
$$




\section{Type I Surveillance Test Example}

Example of a Type I surveillance test for a set of metric mass standards according to design 2, appendix 1 . This set was calibrated by the National Bureau of Standards. The National Bureau of Standards Report of Calibration Test No. 200390 is reproduced on pages 45-48. The standards used (other than the set) are 1isted below together with their apparent mass corrections and uncertainties. The balances used and their standard deviation for one double substitution weighing are also listed. The double substitution weighing method is used. The standard deviation of the calibration mass measurement process is not known, so an estimate is computed from the reported uncertainties, as described in section 3.2, and used in computing the surveillance limits.

\begin{tabular}{|c|c|c|c|}
\hline Standards & $\begin{array}{l}\text { Apparent Mass } \\
\text { Corr. (mg) } \\
\end{array}$ & $\begin{array}{l}\text { Volume } \\
\left(\mathrm{cm}^{3}\right) \\
\end{array}$ & $\begin{array}{c}\text { Uncertainty } \\
(\mathrm{mg})\end{array}$ \\
\hline $\mathrm{S} 100 \mathrm{~g}$ & -0.019 & 12.822 & 0.015 \\
\hline h $10 \mathrm{mg}$ & +0.0450 & 0.0037 & 0.0006 \\
\hline h $\quad 5 \mathrm{mg}$ & +0.0045 & 0.0018 & 0.0005 \\
\hline
\end{tabular}

Balance
Laboratory Designation

Standard

Deviation Capacity

$\mathrm{H}-200$

(mg)

(g)

M -10

0.015

$200 \mathrm{~g}$

0.003

$20 \mathrm{~g}$ 
In the following, "US" will denote the uncertainty of the standard and "S.D." the standard deviation of the process:

For $100 \mathrm{~g}-\mathrm{S} 100 \mathrm{~g}$

$$
\begin{aligned}
\mathrm{U}_{\mathrm{S}} & =0.015 \mathrm{mg} \\
\text { S.D. } & =0.015 \mathrm{mg} \\
\mathrm{s} 1 & =0.015+3(0.015)=\underline{0.060 \mathrm{mg}}
\end{aligned}
$$

In the following, "U $U_{C}$ " will denote the uncertainty (see Equation (2) Page 7, and "S.D." the standard deviation of the process:

For $100 \mathrm{~g}-\Sigma 100 \mathrm{~g}$

$$
\begin{aligned}
U_{c} & =\sqrt{.015^{2}+.011^{2}+.012^{2}+.010^{2}} \\
& =\sqrt{.000225+.000121+.000144+.0001} \\
& =\sqrt{.00059} \\
U_{c} & =0.024 \mathrm{mg} \\
\text { S.D. } & =0.015 \mathrm{mg} \\
\text { S1 } & =0.024+3(0.015)=0.069 \mathrm{mg}
\end{aligned}
$$

For $20 g-\Sigma 20 g$

$$
\begin{aligned}
U_{c} & =\sqrt{.010^{2}}+.013^{2}+.007^{2}+.004^{2}+.003^{2} \\
& =\sqrt{.0001+.000169+.000049+.000016+.000009} \\
& =\sqrt{.000343} \\
U_{c} & =0.019 \mathrm{mg} \\
\text { S.D. } & =0.003 \mathrm{mg} \\
\text { sI } & =0.019+3(0.003)=0.028 \mathrm{mg}
\end{aligned}
$$




$$
\text { For } \begin{aligned}
2 \mathrm{~g} & -\Sigma 2 \mathrm{~g} \\
\mathrm{U}_{\mathrm{c}} & =\sqrt{.0032^{2}+.0030^{2}+.0016^{2}+.0011^{2}+.0008^{2}} \\
& =\sqrt{.00001+.000009+.00000256+.0000012+.00000064} \\
& =\sqrt{.00002341} \\
\mathrm{U}_{\mathrm{C}} & =0.0048 \\
\text { S.D. } & =0.003 \mathrm{mg} \\
\text { s1 } & =0.0048+3(0.003)=0.014 \mathrm{mg}
\end{aligned}
$$

For $200 \mathrm{mg}-\Sigma 200 \mathrm{mg}$

$$
\begin{aligned}
\mathrm{U}_{\mathrm{c}} & =\sqrt{.0008^{2}+.0008^{2}+.0005^{2}+.0005^{2}+.0005^{2}} \\
& =\sqrt{.00000064+.00000064+.00000025+.00000025+.00000025} \\
& =\sqrt{.00000203} \\
\mathrm{U}_{\mathrm{c}} & =0.0014 \mathrm{mg}
\end{aligned}
$$

S.D. $=0.003 \mathrm{mg}$

$$
\mathrm{s} 1=0.0014+3(0.003)=0.010 \mathrm{mg}
$$

For $20 \mathrm{mg}-\Sigma 20 \mathrm{mg}$

$$
\begin{aligned}
U_{C} & =\sqrt{.00042^{2}+.00059^{2}}+.00049^{2}+.00052^{2}+.00045^{2} \\
& =\sqrt{.000000176+.000000348+.000000240+.000000270+.00000020} \\
& =\sqrt{.000001234} \\
U_{C} & =0.0011 \mathrm{mg} \\
\text { S.D. } & =0.003 \mathrm{mg} \\
\text { sl } & =0.0011+3(0.003)=\underline{0.010 \mathrm{mg}}
\end{aligned}
$$


For $3 m g-\sum 3 m g$

$$
\begin{aligned}
\mathrm{U}_{\mathrm{c}} & =\sqrt{.00052^{2}+.00045^{2}+.00059^{2}} \\
& =\sqrt{.000000270+.000000202+.000000349} \\
& =\sqrt{.00000082} \\
\mathrm{U}_{\mathrm{C}} & =0.00091 \mathrm{mg} \\
\text { S.D. } & =0.003 \mathrm{mg} \\
\text { s1 } & =0.00091+3(0.003)=0.0099 \mathrm{mg}
\end{aligned}
$$

For the weighings made on the smaller balance, the uncertainty of the values of the weights is small compared to the standard deviation of that balance. Therefore, for all practical purposes, three times the standard deviation of the balance may be taken as the surveillance limit for these weighings. 
The buoyancy corrections, $\Delta \rho \Delta V$, are computed according to the procedure set forth in section 5.2 , using the formula:

$$
\text { buoyancy correction }=\left(\beta-\rho_{n}\right)\left(V_{C}-V_{D}\right)
$$

Consider the weighing $100 \mathrm{~g}-\mathrm{S} 100 \mathrm{~g}=\mathrm{a}$

where

$$
\begin{aligned}
& \rho=1.17 \mathrm{mg} / \mathrm{cm}^{3} \text { air density at time of weighing } \\
& \rho_{\mathrm{n}}=1.20 \mathrm{mg} / \mathrm{cm}^{3} \text { density of normal air } \\
& \begin{aligned}
& V_{C}=12.821 \mathrm{~cm}^{3} \text { volume of } 100 \mathrm{~g} \text { weight of set under } \\
& \text { test, from Report of Calibration }
\end{aligned} \\
& \mathrm{V}_{\mathrm{D}}=12.822 \mathrm{~cm}^{3} \text { volume of } \mathrm{S} 100 \mathrm{~g} \text { standard } \\
& \text { buoyancy correction }=(1.17-1.20)(12.821-12.822) \\
& =(-0.03)(-0.001) \\
& =+0.00003 \mathrm{mg}
\end{aligned}
$$

This amount is insignificant compared to the surveillance limit of $0.060 \mathrm{mg}$ and may be ignored. Similarly, the differences in the volumes in the weighings $100 \mathrm{~g}-\Sigma 100 \mathrm{~g}$ and $20 \mathrm{~g}-\sum 20 \mathrm{~g}$ are small enough so that the buoyancy corrections are negligible. But, in the weighings $2 \mathrm{~g}-\Sigma 2 \mathrm{~g}$ and $200 \mathrm{mg}-$ ¿200mg weights of differing densities are involved. Consequently, the volumes of the individual weight and the summation of weights are different.

The volumes are:

For the weighing $2 \mathrm{~g}-\sum 2 \mathrm{~g}$ :

\section{Weights}

$2 \mathrm{~g}$
Volumes

$0.2564 \mathrm{~cm}^{3}$

$$
\begin{array}{cc}
1 \mathrm{~g} & 0.1282 \mathrm{~cm}^{3} \\
500 \mathrm{mg} & 0.0301 \mathrm{~cm}^{3} \\
300 \mathrm{mg} & 0.0181 \mathrm{~cm}^{3} \\
200 \mathrm{mg} & 0.0120 \mathrm{~cm}^{3} \\
\hline
\end{array}
$$

$0.1884 \mathrm{~cm}^{3}$

The actual air density, $\rho$, is the same as for $100 \mathrm{~g}-\Sigma 100 \mathrm{~g}$.

$$
\begin{aligned}
\text { buoyancy correction } & =(1.17-1.20)(0.2564-0.1884) \\
& =(-0.03)(+.0680) \\
& =-0.0020 \mathrm{mg}
\end{aligned}
$$

This buoyancy correction, while relatively small compared to the surveillance limit, is not insignificant and must be applied to the measured difference between $2 \mathrm{~g}$ and $\Sigma 2 \mathrm{~g}$. 
For the weighing $200 \mathrm{mg}-\Sigma 200 \mathrm{mg}$ :

$$
\begin{aligned}
& \text { Weights } \quad \text { Volumes } \\
& 200 \mathrm{mg} \quad 0.01205 \mathrm{~cm}^{3} \\
& 100 \mathrm{mg} \quad 0.00602 \mathrm{~cm}^{3} \\
& 50 \mathrm{mg} \quad 0.00301 \mathrm{~cm}^{3} \\
& 30 \mathrm{mg} \quad 0.01111 \mathrm{~cm}^{3} \\
& \underline{20 \mathrm{mg} \quad 0.00741 \mathrm{~cm}^{3}} \\
& \Sigma 200 \mathrm{mg} \\
& 0.02755 \mathrm{~cm}^{3} \\
& \text { buoyancy correction }=(1.17-1.20)(0.01205-0.02755) \\
& =(-0.03)(+0.01550) \\
& =-0.00046 \mathrm{mg}
\end{aligned}
$$

This buoyancy correction is small compared to the surveillance limits for this comparison and in most cases can be ignored.

For the weighing $20 \mathrm{mg}-\Sigma 20 \mathrm{mg}$ :

$$
\begin{aligned}
& \text { Weights } \\
& 20 \mathrm{mg} \quad 0.00741 \mathrm{~cm}^{3}
\end{aligned}
$$

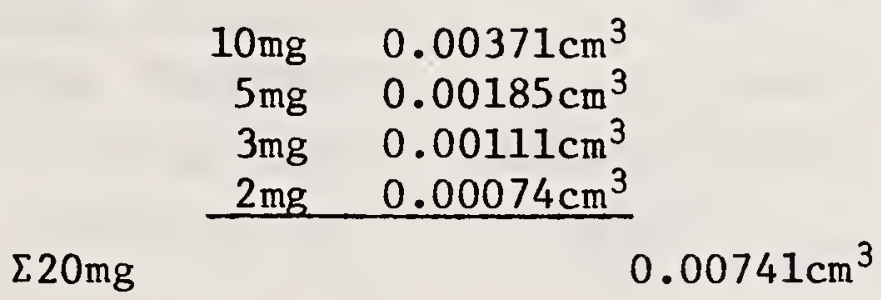

The volumes of the two masses are equal, therefore the buoyancy correction is zero.

For the weighing $3 \mathrm{mg}-\Sigma 3 \mathrm{mg}$ :

Weights

$3 \mathrm{mg}$

$2 \mathrm{mg} \quad 0.00074 \mathrm{~cm}^{3}$

$\underline{1 \mathrm{mg} \quad 0.00037 \mathrm{~cm}^{3}}$

$\Sigma 3 \mathrm{mg}$

The volumes of the two masses are equal, therefore the buoyancy correction is zero.
Volumes

$0.00111 \mathrm{~cm}^{3}$

$$
0.00111 \mathrm{~cm}^{3}
$$


The expected differences are computed from the reported values as follows: (see report on page 47 ).

For the weighing $100 \mathrm{~g}-\mathrm{S} 100 \mathrm{~g}$ :

Weights

$\frac{\text { Values }}{100 \mathrm{~g} \text { S100g }}$

\begin{tabular}{llr}
$100 \mathrm{~g}$ & \multicolumn{1}{c}{$-0.058 \mathrm{mg}$} \\
S100g & \multicolumn{1}{c}{$-0.019 \mathrm{mg}$} \\
\cline { 2 - 2 } & $-0.058 \mathrm{mg}$ & $-0.019 \mathrm{mg}$ \\
Expected Diff. $=$ & $-0.039 \mathrm{mg}$
\end{tabular}

For the weighing $100 \mathrm{~g}-\Sigma 100 \mathrm{~g}$ :

Weights

$100 \mathrm{~g}$

$50 \mathrm{~g}$

$30 \mathrm{~g}$

$20 \mathrm{~g}$

Sums

$\frac{\text { Values }}{100 \mathrm{~g} \sum 100 \mathrm{~g}}$

$-0.0589 \mathrm{mg}$

$-0.0133 \mathrm{mg}$

$-0.0134 \mathrm{mg}$

$+0.0330 \mathrm{mg}$

$-0.0589 \mathrm{mg}+0.0063 \mathrm{mg}$

Expected Diff. $=-0.065 \mathrm{mg}$

For the weighing $20 \mathrm{~g}-\Sigma 20 \mathrm{~g}$ :

Weights

$20 \mathrm{~g}$

$10 \mathrm{~g}$

$5 \mathrm{~g}$

$3 \mathrm{~g}$

$2 \mathrm{~g}$

Sums

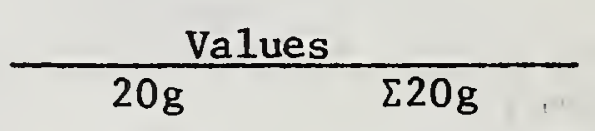

$+0.0330 \mathrm{mg}$

$$
\begin{array}{rr}
-0.0378 \mathrm{mg} \\
-0.0065 \mathrm{mg} \\
+0.0191 \mathrm{mg} \\
+0.0066 \mathrm{mg} \\
\hline+0.0330 \mathrm{mg} \quad-0.0186 \mathrm{mg}
\end{array}
$$

Expected Diff. $=+0.0516 \mathrm{mg}$ 
For the weighing $2 g-\Sigma 2 g$ :

Weights

$\begin{array}{lll}2 \mathrm{~g} & +0.0066 \mathrm{mg} & \\ 1 \mathrm{~g} & & -0.0216 \mathrm{mg} \\ 500 \mathrm{mg} & & -0.0005 \mathrm{mg} \\ 300 \mathrm{mg} & & -0.0041 \mathrm{mg} \\ 200 \mathrm{mg} & & -0.0049 \mathrm{mg} \\ \text { Sums } & +0.0066 \mathrm{mg} & -0.0311 \mathrm{mg} \\ \text { Expected Diff. }=+0.0377 \mathrm{mg} & \end{array}$

For the weighing $200 \mathrm{mg}-\Sigma 200 \mathrm{mg}$ :

Weights

\begin{tabular}{ccc}
\cline { 2 - 3 } $200 \mathrm{mg}$ & \multicolumn{1}{c}{$200 \mathrm{mg}$} & \multicolumn{2}{c}{$\Sigma 200 \mathrm{mg}$} \\
$100 \mathrm{mg}$ & & $+0.0008 \mathrm{mg}$ \\
$50 \mathrm{mg}$ & & $+0.0074 \mathrm{mg}$ \\
$30 \mathrm{mg}$ & & $-0.0049 \mathrm{mg}$ \\
$20 \mathrm{mg}$ & & $-0.0020 \mathrm{mg}$ \\
Sums & $-0.0049 \mathrm{mg}$ & $+0.0013 \mathrm{mg}$ \\
Expected Diff. $=-0.0062 \mathrm{mg}$ &
\end{tabular}

For the weighing $20 \mathrm{mg}-\Sigma 20 \mathrm{mg}$ :

\begin{tabular}{ccc} 
Weights & \multicolumn{2}{c}{ Values } \\
\cline { 2 - 3 } $20 \mathrm{mg}$ & $-0.0020 \mathrm{mg}$ & \\
$10 \mathrm{mg}$ & & $+0.0028 \mathrm{mg}$ \\
$5 \mathrm{mg}$ & $+0.0065 \mathrm{mg}$ \\
$3 \mathrm{mg}$ & $+0.0030 \mathrm{mg}$ \\
$2 \mathrm{mg}$ & & $-0.0142 \mathrm{mg}$ \\
Sums & $-0.0020 \mathrm{mg}$ & $-0.0019 \mathrm{mg}$ \\
Expected Diff. $=-0.0001 \mathrm{mg}$ &
\end{tabular}


For the weighing $3 \mathrm{mg}-\sum 3 \mathrm{mg}$ :

\begin{tabular}{ccc} 
Weights & \multicolumn{2}{c}{ Values } \\
\cline { 2 - 3 } $3 \mathrm{mg}$ & $+0.0030 \mathrm{mg}$ & $\sum 3 \mathrm{mg}$ \\
$2 \mathrm{mg}$ & & $-0.0142 \mathrm{mg}$ \\
$1 \mathrm{mg}$ & & $+0.0091 \mathrm{mg}$ \\
Sums & $+0.0030 \mathrm{mg}$ & $-0.0051 \mathrm{mg}$ \\
Expected Diff. $=+0.0081 \mathrm{mg}$ &
\end{tabular}




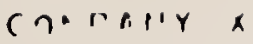

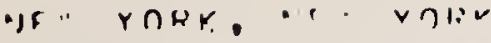

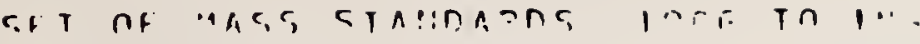

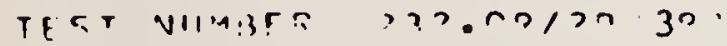

SI, M M A Y

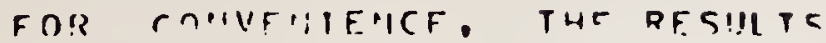
OF THIS "NOK $\triangle R F$ SIIANATIZFO IA: TANIFS I ANT IT. TIH VAIIIES ACSIGAIEN ADE .. ITH DFEFDFPCE TO THT. STA UDARDS IRTITIFIFR NY THE MATA SIIEFTS. TUR INNERTAINTY FITIRE IS AN FXPRFSEIOA TF THF OVFDALI. IINEOTAIITY IIGIMG THRFF STARIMARP DEVIATINIS IS A LIMIT TO THE FFrECT OF EPIRAM ERFOQC OF THF M.TASHEFHEUT ASSOCIATER "ITH THF PATA CIIRFHEPT DINCESSFS. THF :OAGPI-

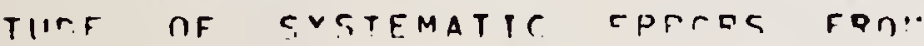
SNIIOSFS OTUF: THAN TIIT IISF DF

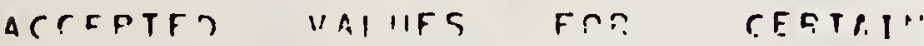

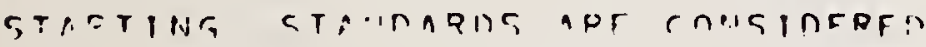

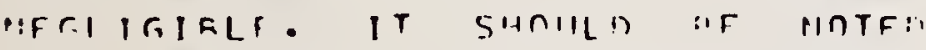

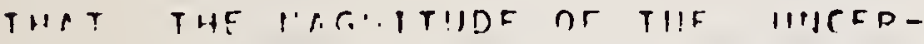
TA I:TY PFFLECTS THE PFPFAMARCF OF


FCTARI-ISH THESF VALIIFS. THE MASS IIJIT. AS FFALITAFLF IH! AIITTEO

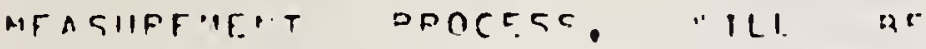

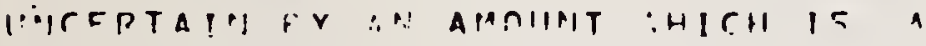

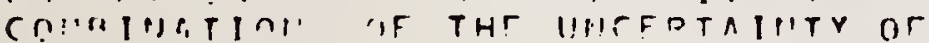

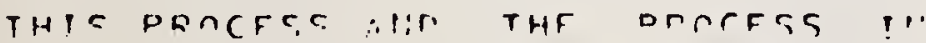

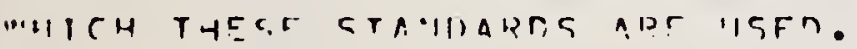

THF LISTER IN TAMIA I ABF zESER n. A

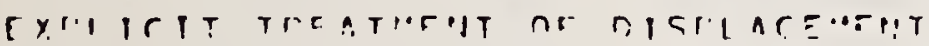

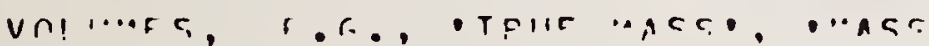

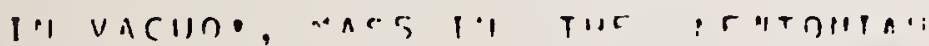

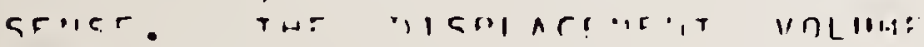

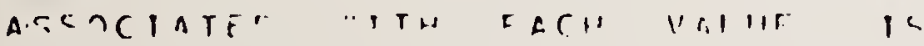

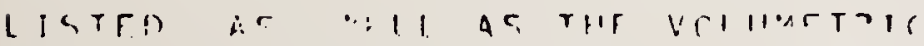
Cotelcit:

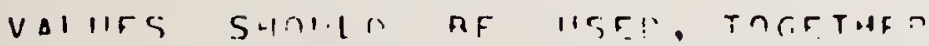
"iti: appronojetf conerotina ran.

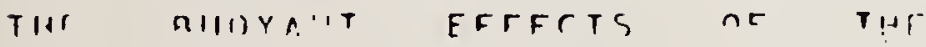

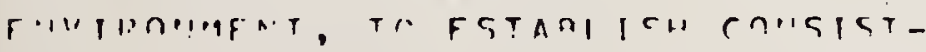

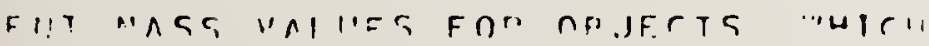

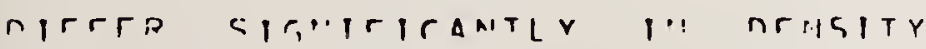

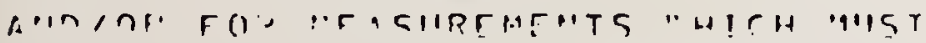

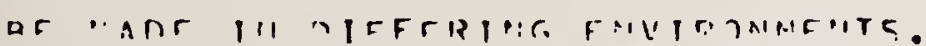

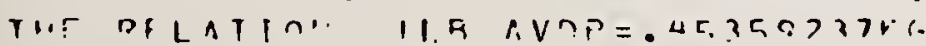

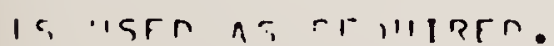

TIF. FSTIHATCD "ASE VALIIES I. ISTEN I" TAELF I ARE PASFE UN AII IMPI ISIT TREATMFHT OF MISPLACEMIIT

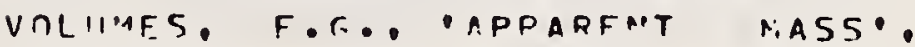

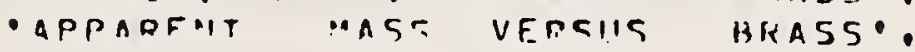
- appalefit mass vepciss density - i thf valure apf listad as CDIRERTIDPS TO AF APPLIFD TO THE LISTFN IIIAIIAL VALIIF IA POSITIVE CORGFCTIOA IHOISATES THAT THE MASS IS LADRFO THAII TWF STATFO HIJMIHAL VALIIF OY THE AHD!IA!T UF THE COROFCTIO:1. THFSE VALIIES ARE COIMUITFN FROM THF VAIIIFS BASEII ON AA FXPLICIT TRFATMFHT OF NISPLACE AEA!T VOLWHES IISING THF FOLLO:IIIG NEFIMINS FELATIN:IS AND ARE IINCENTAI:H HY THE AIMIINT CHOBII IN TABIF I.

THE ATJIITARHT OF :HFIGHTS TO

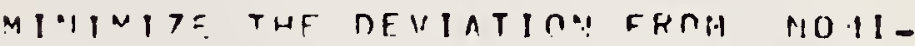

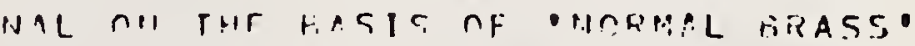

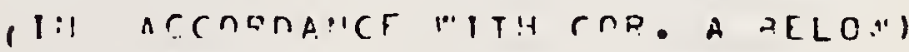

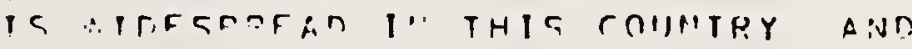
1"! MA"IY DAPTS OF THF WORLD. VALIIEC STATER ON FITHER RASIS ITERIALLY COISISTERT ANT NTFIUTTE. TWFRT IS, HOWEVER, A CVCTEMATIS RIFFrPFHCF DETHEN THE VALIITE ACEIGNEO OPI FACH RASIJ. THF VALIF CN THE "ASIS OF DIFHSITY

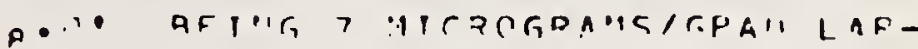

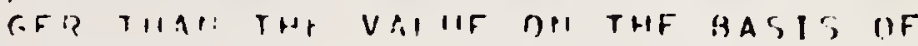
IIAO:AI. WWASC. THIS SYSTIMATIC nIFTCDFACE IS RIFARI V MFTECTALLE

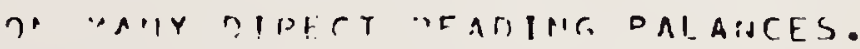

rODHFrTIAR A - MPPAPFiT IASS

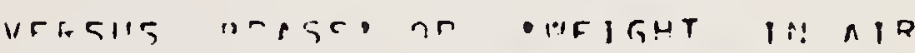
ASAlHat WOASC, IS DFTED:"IMFO FY A HYSOTHETICAL "FIGHINR OF THF

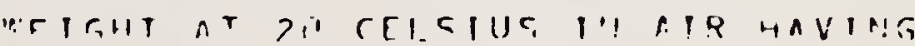

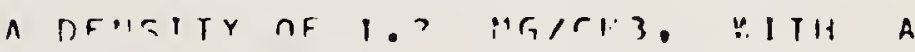

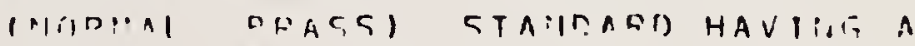

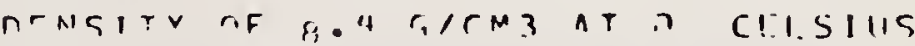

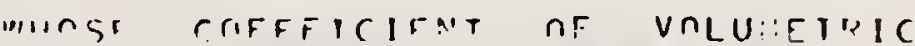

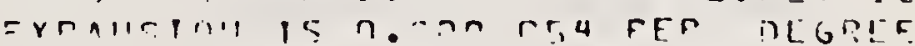

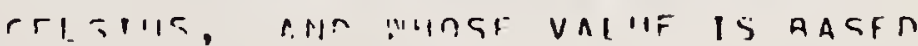

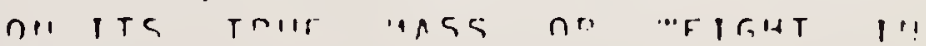
var 110 . 
COMPANY $X$

NEW YORK, NEW YORK

SET OF MASS STANDARDS $100 G$ TO IMG

TEST NUMBER 232.09/200390

CORRECTION B - 'APPARENT MASS

VERSUS DENSITY $8.0^{\prime}$ IS DETERMINED

BY A HYPOTHETICAL WEIGHING OF THE WEIGHT, IN AIR HAVING A DENSITY OF $1.2 \mathrm{MG} / \mathrm{CM} 3$, WITH A STANDARD HAVING A DENSITY OF 8.0 G/CM3 AT 20 CELSIUS, AND WHOSE VALUE IS BASED ON ITS TRUE MASS OR WEIGHT IN AIR.

SAMPLE REPORT (CONTINUED) 


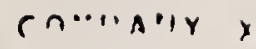

MF "

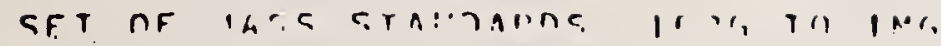

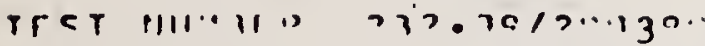

ITF:"

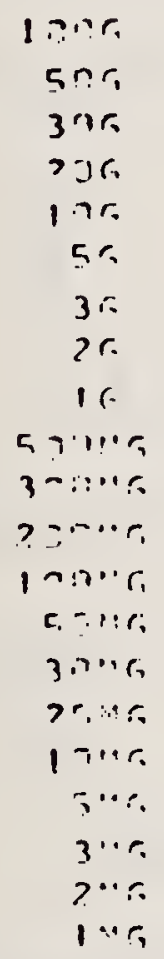

TABIF I

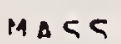

(:)

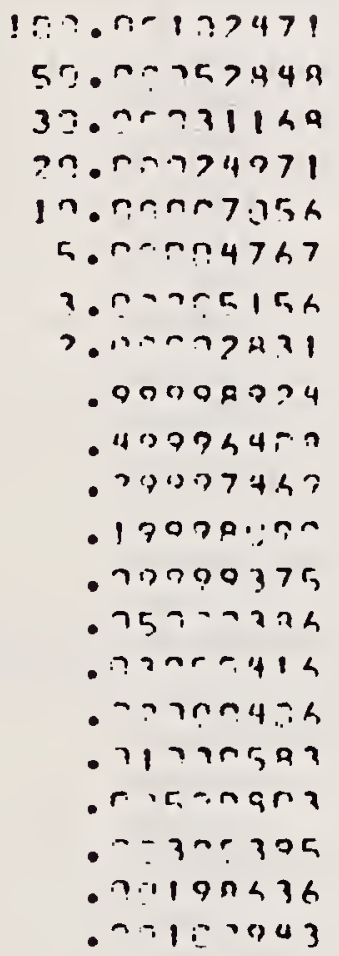

HNEFOTAIHTY $(r:)$

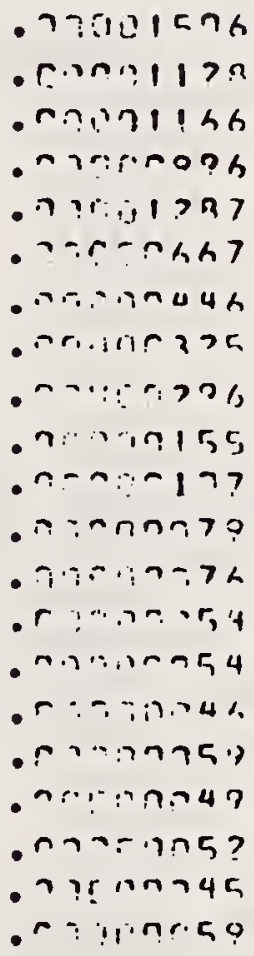

VOI AT IN COFF OF EXD
(CMU)

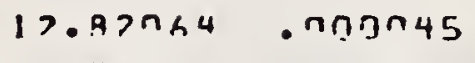

6. $4 \ln 32.0 n 5045$

?. $44519.9 n 9 ? 45$

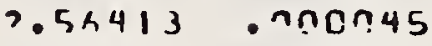

1.7.7?6 . r. $507+5$

.

.394h? . .0तก

- 25k41 - vnofits

- 1วงวr . . r.า745

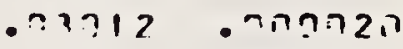

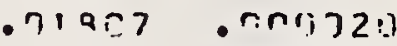

.

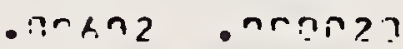

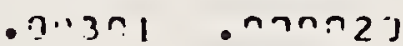

- 18111 .nก?n64

. ir741. vrnab4

. r. $371.05 ? 769$

- ก:-195 .?7rn69

.

on-ria .nnigns9

- $\operatorname{in} 37$ - inn69 


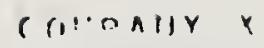

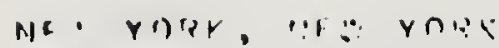

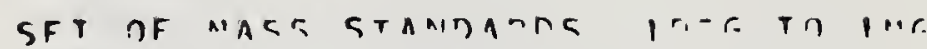

\section{TAMIF II}

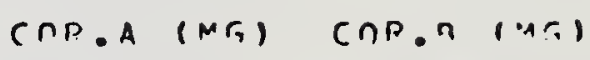

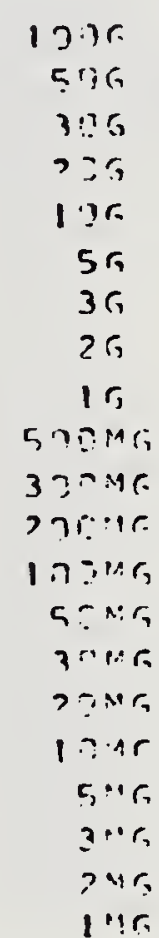

$-.05993$

$-.17 .73$

$-.71747$

- ? $>90$

- $\because 3791$

- . On651

- 19:5

- जक64

-.. 2163

-.กก?55

-. - 459

- in 405

- :-na

- in 747

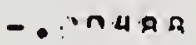

- onja

- roja

- OnkE?

- नि?

- r 1424

or 013
- R4⿻ina 3

- 3615

. 19627

.17777

. 13209

- ? ? a य

- -4ron?

- i> 71.7

-.?1461

- .7? 294

-. . 199

-.135h

-.715?

-.7n46?

- inlay

- in?Ro

- $? r .156$

- irina

-. $: 1423$

.0 .913
-.9775 


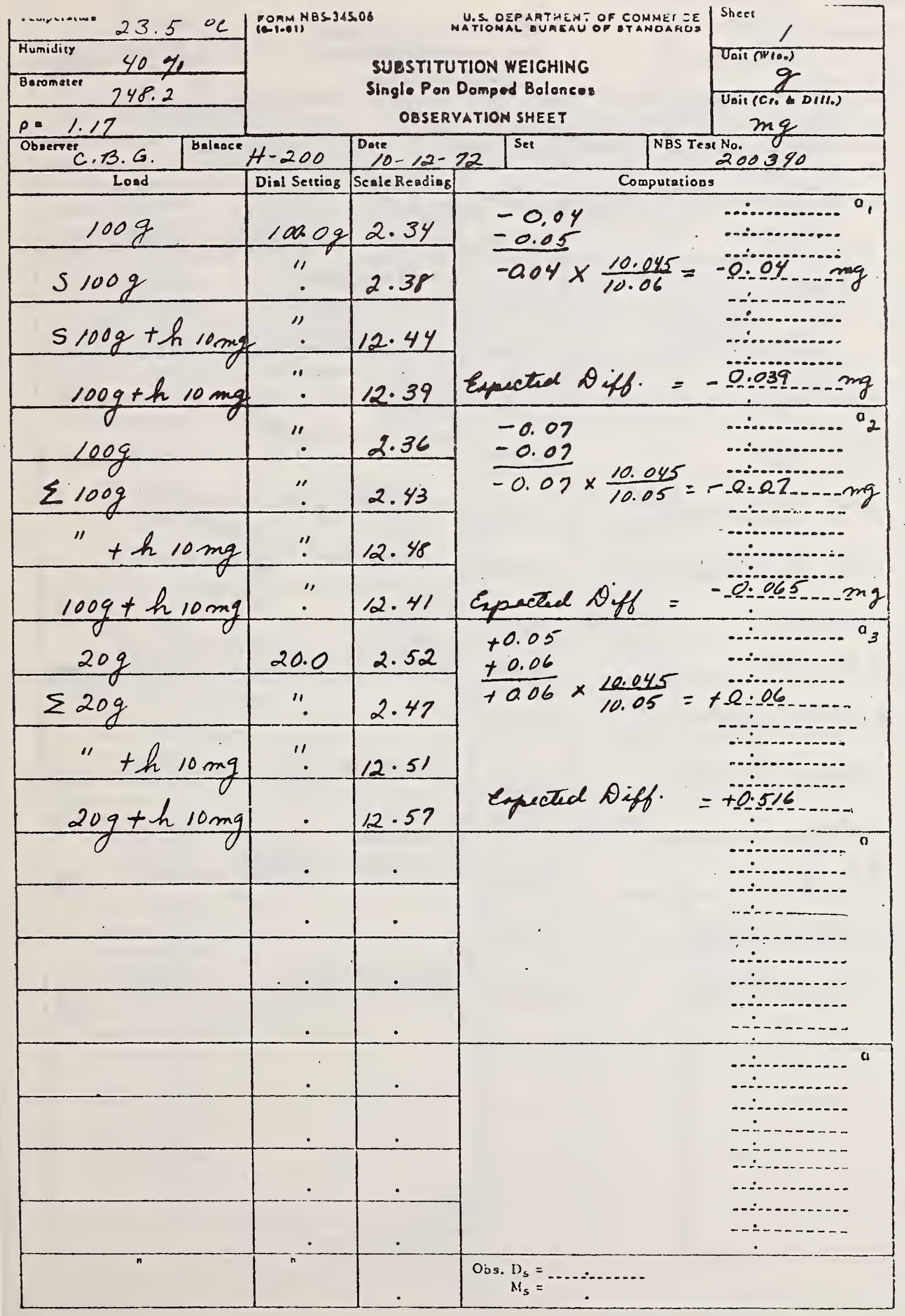




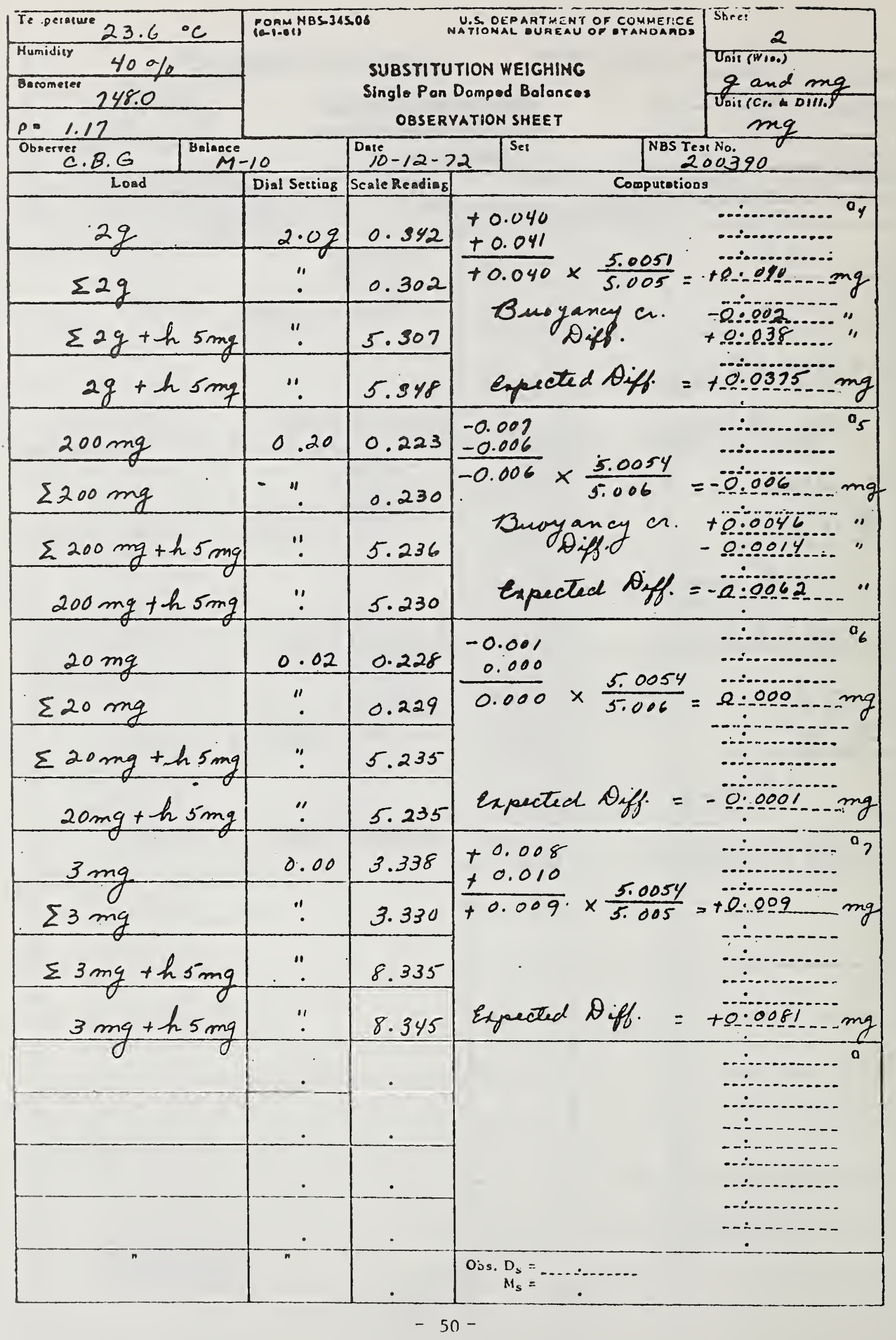


This example of a Type II Surveillance Test is for a set of metric mass standards according to Design 7 , appendix 1 . This set was calibrated by the National Bureau of Standards and reported under National Bureau of Standards Report of Calibration, Test No. 200390. The report is reproduced on page 47. This is the same set which was used for the example of the Type I Surveillance Test. The only standards (other than the set under test) used in this example are the sensitivity weights listed below, with their apparent mass corrections and uncertainties. The balances used and their standard deviation for a double substitution weighing are also listed. The double substitution method of weighing is used. The standard deviation of the calibration mass measurement is not known, so an estimate is computed from the reported uncertainties of the weights being tested, as described in section 3.2 , and used in computing the surveillance limits.

\begin{tabular}{ccc}
$\begin{array}{c}\text { Sensitivity } \\
\text { Weight }\end{array}$ & $\begin{array}{c}\text { Apparent Mass } \\
\text { Corr. (mg) }\end{array}$ & $\begin{array}{c}\text { Uncertainty } \\
\text { (mg) }\end{array}$ \\
\cline { 1 - 2 } h10mg & +0.0450 & 0.0006 \\
h 5mg & +0.0045 & 0.0005
\end{tabular}

\begin{tabular}{|c|c|c|}
\hline $\begin{array}{c}\text { Balance } \\
\text { (Laboratory Designation) }\end{array}$ & $\begin{array}{c}\text { Standard Deviation } \\
(\mathrm{mg})\end{array}$ & $\begin{array}{c}\text { Capacity } \\
\mathrm{g} \\
\end{array}$ \\
\hline$H-200$ & 0.015 & $200 \mathrm{~g}$ \\
\hline$M-10$ & 0.003 & $20 \mathrm{~g}$ \\
\hline
\end{tabular}


In the following " $U_{C}$ " will denote the uncertainty (see Equation (2) Page 7) and "S.D." the estimate of the standard deviation. $\sigma_{B}$ denotes the standard deviation of the balance used.

For series 1: $100 \mathrm{~g}, 100 \mathrm{~g}^{\prime}, \sum 100 \mathrm{~g}$

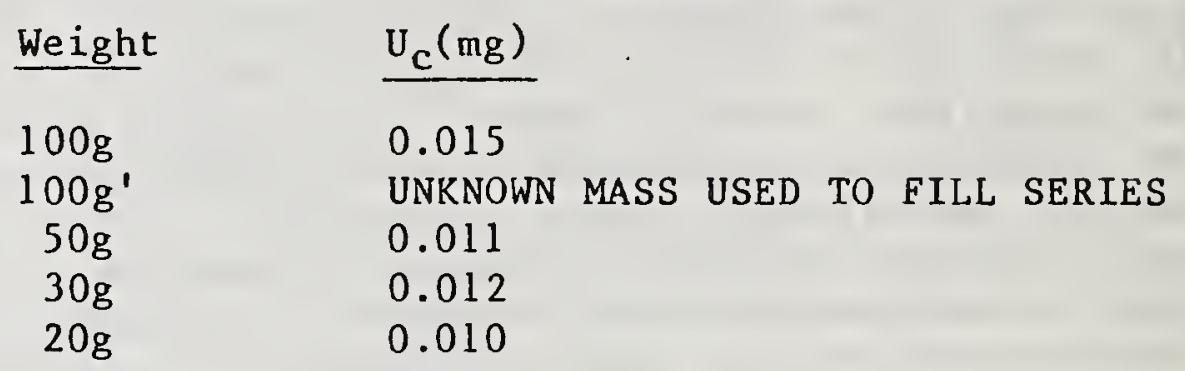

Standard deviation of balance $\mathrm{H}-200=0.015 \mathrm{mg}$

$$
\begin{aligned}
U_{c} & =\sqrt{.015^{2}+.011^{2}+.012^{2}+.010^{2}} \\
& =\sqrt{.000225+.000121+.000144+.0001} \\
& =\sqrt{.00059} \\
U_{c} & =0.024 \mathrm{mg} \\
\text { S.D. } & =3 \sqrt{2 / 3} \sigma_{\mathrm{B}} \\
& =3 \sqrt{2 / 3}(.015) \\
& =3 \sqrt{.66666}(.015) \\
& =3(.81649)(.015) \\
\text { S.D. } & =0.037 \mathrm{mg}
\end{aligned}
$$

sl for $\sum 100 \mathrm{~g}=0.024+0.037=0.061 \mathrm{mg}$

Since $100 \mathrm{~g}^{\prime}$ is assumed to be an unknown weight, a surveillance limit for it cannot be computed. 
For series 2: $\quad 30 \mathrm{~g}, \sum 30 \mathrm{~g}_{1}, \sum 30 \mathrm{~g}_{2}$

\begin{tabular}{|c|c|}
\hline Weight & $\mathrm{U}_{\mathrm{c}}(\mathrm{mg})$ \\
\hline $30 \mathrm{~g}$ & 0.012 \\
\hline $20 \mathrm{~g}$ & 0.010 \\
\hline $10 \mathrm{~g}$ & 0.013 \\
\hline $5 g$ & 0.0067 \\
\hline $3 g$ & 0.0045 \\
\hline $2 g$ & 0.0032 \\
\hline
\end{tabular}

Standard deviation of balance $\mathrm{H}-200=0.015 \mathrm{mg}$

$$
\begin{aligned}
U_{c} & =\sqrt{.012^{2}+.010^{2}+.013^{2}} \\
& =\sqrt{.000144+.0001+.000169} \\
& =\sqrt{.000413} \\
U_{c} & =0.020 \mathrm{mg}
\end{aligned}
$$

S.D. = SAME AS IN SERIES $1(0.037 \mathrm{mg})$

sl for $\Sigma 30 g_{1}=0.020+0.037=0.057 \mathrm{mg}$

$$
\begin{aligned}
U_{C} & =\sqrt{.012^{2}+.010^{2}+.0067^{2}+.0045^{2}+.0032^{2}} \\
& =\sqrt{.000144+.0001+.0000448+.00002025+.00001024} \\
& =\sqrt{.000319} \\
U_{C} & =0.018 \mathrm{mg} \\
\text { S.D. } & =\text { SAME AS IN SERIES 1 }(0.037 \mathrm{mg})
\end{aligned}
$$

sl for $\sum 30 \mathrm{~g}_{2}=0.018+0.037=0.055 \mathrm{mg}$ 
For series $3: 3 g, \sum 3 g_{1}, \Sigma 3 g_{2}$

\begin{tabular}{|c|c|}
\hline We ight & $\mathrm{U}_{\mathrm{c}} \quad(\mathrm{mg})$ \\
\hline $3 \mathrm{~g}$ & .0045 \\
\hline $2 \mathrm{~g}$ & .0032 \\
\hline $1 \mathrm{~g}$ & .0030 \\
\hline $500 \mathrm{mg}$ & .0016 \\
\hline $300 \mathrm{mg}$ & .0011 \\
\hline $200 \mathrm{mg}$ & .0008 \\
\hline
\end{tabular}

Standard deviation of balance $M-10=0.003 \mathrm{mg}$

$$
\begin{aligned}
\mathrm{U}_{\mathrm{C}} & =\sqrt{.0045^{2}+.0032^{2}+.0030^{2}} \\
& =\sqrt{.00002025+.00001024+.000009} \\
& =\sqrt{.00003949} \\
\mathrm{U}_{\mathrm{C}} & =0.0063 \mathrm{mg} \\
\text { S.D. } & =3 \sqrt{2 / 3} \sigma_{\mathrm{B}} \\
& =3 \sqrt{2 / 3}(.003) \\
& =3 \sqrt{.66666}(.003) \\
& =3(.81649)(.003) \\
\text { S.D. } & =0.0073 \mathrm{mg} .
\end{aligned}
$$

sl for $\Sigma 3 g_{1}=0.0063+0.0073=0.014 \mathrm{mg}$

$$
\begin{aligned}
U_{c} & =\sqrt{.0045^{2}+.0032^{2}+.0016^{2}+.0011^{2}+.0008^{2}} \\
& =\sqrt{.00002025+.00001024+.00000256+.00000121+.00000054} \\
& =\sqrt{.0000349} \\
U_{C} & =0.0059 \mathrm{mg} \\
\text { S.D. } & =\text { SAME AS FOR } \sum 3_{\mathrm{g}}(0.0073 \mathrm{mg})
\end{aligned}
$$

sl for $\Sigma 3 g_{2}=0.0059+0.0073=0.013 \mathrm{mg}$ 
For series 4: $300 \mathrm{mg}, \sum 300 \mathrm{mg}_{1}, \sum 300 \mathrm{mg}_{2}$

$\begin{array}{ccc}\text { Weight } & & U_{c}(\mathrm{mg}) \\ 300 \mathrm{mg} & & 0.0011 \\ 200 \mathrm{mg} & & 0.0008 \\ 100 \mathrm{mg} & & 0.0008 \\ 50 \mathrm{mg} & & 0.0005 \\ 30 \mathrm{mg} & & 0.0005 \\ 20 \mathrm{mg} & & 0.0005\end{array}$

Standard deviation of balance $M-10=0.003 \mathrm{mg}$

$$
\begin{aligned}
\mathrm{U}_{\mathrm{c}} & =\sqrt{.0011^{2}+.0008^{2}+.0008^{2}} \\
& =\sqrt{.00000121+.00000064+.00000064} \\
& =\sqrt{.00000249} \\
\mathrm{U}_{\mathrm{c}} & =0.0016 \mathrm{mg}
\end{aligned}
$$

S.D. = SAME AS IN SERIES $3(0.0073 \mathrm{mg})$

sl for $\sum 300 \mathrm{~g}_{1}=0.0016+0.0073=0.0089 \mathrm{mg}$

$$
\begin{aligned}
U_{c} & =\sqrt{.0011^{2}+.0008^{2}+.0005^{2}+.0005^{2}+.0005^{2}} \\
& =\sqrt{.00000121+.00000064+.00000025+.00000025+.00000025} \\
& =\sqrt{.0000026} \\
U_{C} & =0.0016 \mathrm{mg} \\
\text { S.D. } & =\text { SAME AS FOR } \sum 300 \mathrm{mg}_{1}(0.0073 \mathrm{mg})
\end{aligned}
$$

sl for $\sum 300 \mathrm{mg}_{2}=0.0016+0.0073=0.0089 \mathrm{mg}$ 
For series 5: $30 \mathrm{mg}, \quad 530 \mathrm{mg}_{1}, \quad 230 \mathrm{mg}_{2}$

\begin{tabular}{ccc} 
Weight & & $U_{c}(\mathrm{mg})$ \\
\hline $30 \mathrm{mg}$ & & 0.00054 \\
$20 \mathrm{mg}$ & & 0.00046 \\
$10 \mathrm{mg}$ & & 0.00059 \\
$5 \mathrm{mg}$ & & 0.00049 \\
$3 \mathrm{mg}$ & & 0.00052 \\
$2 \mathrm{mg}$ & & 0.00045
\end{tabular}

Standard deviation for balance $M-10=0.003 \mathrm{mg}$

$$
\begin{aligned}
U_{c} & =\sqrt{.00054^{2}+.00046^{2}+.00059^{2}} \\
& =\sqrt{.000000291+.0000002116+.0000003481} \\
& =\sqrt{.0000008513} \\
U_{c} & =0.00092 \mathrm{mg}
\end{aligned}
$$

S.D. = SAME AS IN SERIES $4(0.0073 \mathrm{mg})$

sl for $\sum 30 \mathrm{mg}_{]}=0.00092+0.0073=0.0082 \mathrm{mg}$

$$
\begin{aligned}
& U_{C}=\sqrt{.00054^{2}+.00046^{2}+.00049^{2}+.00052^{2}+.00045^{2}} \\
& =\sqrt{.0000002916+.0000002116+.0000002401+.0000002704+.0000002025} \\
& =\sqrt{.0000012162} \\
& \mathrm{U}_{\mathrm{c}}=0.0011 \mathrm{mg}
\end{aligned}
$$

S.D. = SAME AS FOR $\sum 30 \mathrm{mg}_{1}(0.0073 \mathrm{mg})$

sl for $\sum 30 \mathrm{mg}_{2}=0.0011+0.0073=0.0084 \mathrm{mg}$ 
For $5 m g-\sum 5 m g$ :

\begin{tabular}{|c|c|}
\hline We ight & $\mathrm{U}_{\mathrm{c}}(\mathrm{mg})$ \\
\hline $5 \mathrm{mg}$ & 0.00049 \\
\hline $3 \mathrm{mg}$ & 0.00052 \\
\hline $2 \mathrm{mg}$ & 0.00045 \\
\hline
\end{tabular}

Standard Deviation of Balance $M-10=0.003 \mathrm{mg}$

$$
\begin{aligned}
U_{c} & =\sqrt{.00049^{2}+.00052^{2}+.00045^{2}} \\
& =\sqrt{.0000002401-.0000002704+.0000002025} \\
& =\sqrt{.000000713} \\
U_{C} & =0.00084 \mathrm{mg} \\
\text { sl } & =.00084+3(.003) \\
& =.00084+.009=0.0098 \mathrm{mg}
\end{aligned}
$$

For $3 m g-\sum 3 m g$

$$
\begin{array}{ccc}
\text { Weight } & & \mathrm{U}_{c}(\mathrm{mg}) \\
\hline 3 \mathrm{mg} & 0.00052 \\
2 \mathrm{mg} & 0.00045 \\
1 \mathrm{mg} & 0.00059
\end{array}
$$

Standard Deviation of Balance $M-10=0.003 \mathrm{mg}$

$$
\begin{aligned}
U_{c} & =\sqrt{.00052^{2}+.00045^{2}+.00059^{2}} \\
& =\sqrt{.0000002704+.0000002025+.0000003481} \\
& =\sqrt{.000000821} \\
U_{C} & =0.00091 \mathrm{mg} \\
\mathrm{sl} & =0.00091+3(.003) \\
& =0.00091+.009=0.0099 \mathrm{mg}
\end{aligned}
$$




\section{Buoyancy Corrections}

The buoyancy corrections $\Delta \rho \Delta V$ are computed according to the procedure set forth in section 5.2 using the formula:

$$
\text { Buoyancy Correction }=\left(\rho-\rho_{n}\right)\left(V_{C}-V_{D}\right)
$$

In this example, only two of the comparisons, $3 g-\sum 3 g_{2}$ and $300 \mathrm{mg}-$ $\sum 300 \mathrm{mg}$, are between weights having different densities. A buoyancy correction need be computed only for these two comparisons. All of the other comparisons are between weights having the same density, so their volume differences are virtually zero and the buoyancy corrections are also virtually zero.

The buoyancy correction for the comparison $3 g-\Sigma 3 g_{2}, a_{2}$ of series 3 , is:

Weights

$3 \mathrm{~g}$

\begin{tabular}{|c|c|c|c|c|c|}
\hline \multirow[t]{5}{*}{$3 g$} & \multicolumn{3}{|r|}{$0.3846 \mathrm{~cm}^{3}$} & \multirow{2}{*}{\multicolumn{2}{|c|}{$\begin{array}{c}\text { from Report } \\
\text { Calibration } \\
\text { " }\end{array}$}} \\
\hline & $2 \mathrm{~g}$ & $0.2564 \mathrm{~cm}^{3}$ & & & \\
\hline & $500 \mathrm{mg}$ & $0.0301 \mathrm{~cm}^{3}$ & & & $" 1$ \\
\hline & $300 \mathrm{mg}$ & $0.0181 \mathrm{~cm}^{3}$ & - & & " \\
\hline & $200 \mathrm{mg}$ & $0.0120 \mathrm{~cm}^{3}$ & & & $" 1$ \\
\hline$\sum 3 g$ & & & $0.3166 \mathrm{~cm}^{3}$ & & " \\
\hline$=1.16 \mathrm{mg} / \mathrm{cm}^{3}$ & Air & - density at & time of we & ighing & \\
\hline
\end{tabular}

Buoyancy correction $=(1.16-1.20)(0.3846-0.3166)=-0.0027 \mathrm{mg}$

This is the figure entered on the 3-1's computation sheet under the $\sum 3 g_{2}$ column on the $-\Delta \rho \Delta V$ line, Sheet 2 , Series 3 . Note that it is $-\Delta \rho \Delta \mathrm{V}$ that is called for and the buoyancy correction is $-0.0027 \mathrm{mg}$, therefore, the buoyancy correction is entered as $+0.0027 \mathrm{mg}$. (See section 5.3 .2 ).

The buoyancy correction for the comparison $300 \mathrm{mg}-\Sigma 300 \mathrm{mg}_{2}$, $\mathrm{a}_{2}$ of series 4 , is: 
Weight

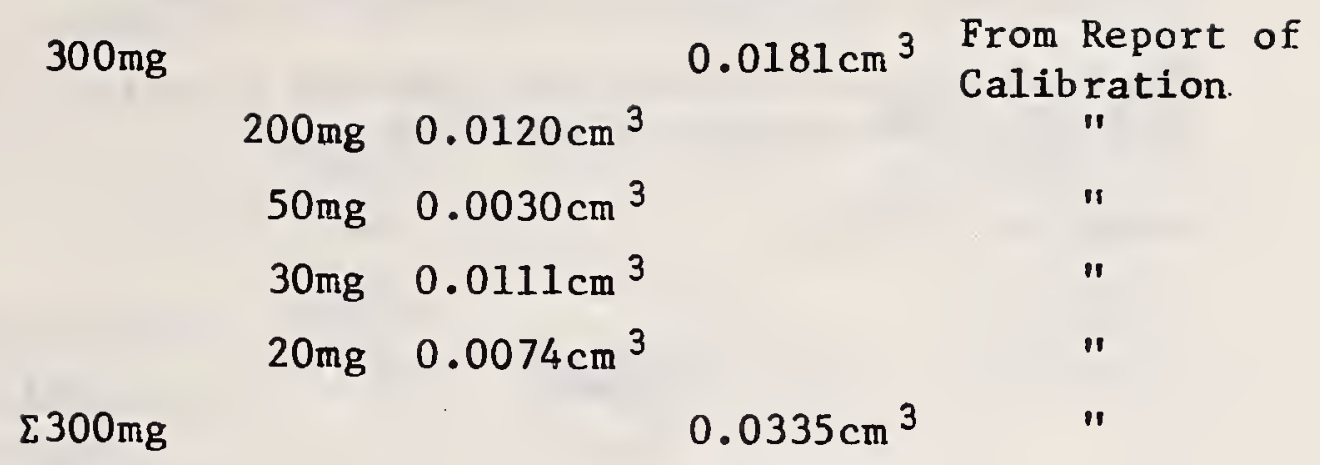

$$
\begin{array}{ll}
\rho=1.16 \mathrm{mg} / \mathrm{cm}^{3} & \text { Air density at time of weighing } \\
\rho_{\mathrm{n}}=1.20 \mathrm{mg} / \mathrm{cm}^{3} & \text { Normal air density }
\end{array}
$$

Buoyancy Correction $=(1.16-1.20)(0.0181-0.0335)=+0.0006 \mathrm{mg}$

This is the figure entered on the 3-1's computation sheet under the $\Sigma 300 \mathrm{mg}_{2}$ column on the $-\Delta \rho \Delta \mathrm{V}$ line, Sheet 2 , Series 4 . Note that it is $-\Delta \rho \Delta \mathrm{V}$ that is called for and that the buoyancy correction is $+0.0006 \mathrm{mg}$, therefore the buoyancy correction is entered as - 0.0006 mg. (See section 5.3.2). 
The expected differences are computed from the reported values as follows: (See report on page 47 ).

Series 1: $\Sigma 100 \mathrm{~g}$

\begin{tabular}{|c|c|c|}
\hline Weight & & $\begin{array}{l}\text { arent Mass } \\
\text { Value }\end{array}$ \\
\hline $50 \mathrm{~g}$ & & $-0.0133 \mathrm{mg}$ \\
\hline $30 \mathrm{~g}$ & & $-0.0134 m g$ \\
\hline $20 \mathrm{~g}$ & & $+0.0330 \mathrm{mg}$ \\
\hline$\sum 100 \mathrm{~g}$ & Expected Value & $+0.0063 \mathrm{mg}$ \\
\hline
\end{tabular}

Series 2: $\quad \sum 30 \mathrm{~g}_{1}$

\begin{tabular}{crr}
$20 \mathrm{~g}$ & $+0.0330 \mathrm{mg}$ \\
$10 \mathrm{~g}$ & & $-0.0378 \mathrm{mg}$ \\
\hline$\sum 30 \mathrm{~g}_{1}$ & Expected Value & $-0.0048 \mathrm{mg}$
\end{tabular}

Series 2: $\sum 30 \mathrm{~g}_{2}$

\begin{tabular}{rr}
$20 \mathrm{~g}$ & $+0.0330 \mathrm{mg}$ \\
$5 \mathrm{~g}$ & $-0.0065 \mathrm{mg}$ \\
$3 \mathrm{~g}$ & $+0.0191 \mathrm{mg}$ \\
$2 \mathrm{~g}$ & $+0.0066 \mathrm{mg}$ \\
\hline$\sum 30 \mathrm{~g}_{2}$ Expected Value & $+0.0522 \mathrm{mg}$
\end{tabular}

Series 3: $\quad \sum 3 g_{1}$

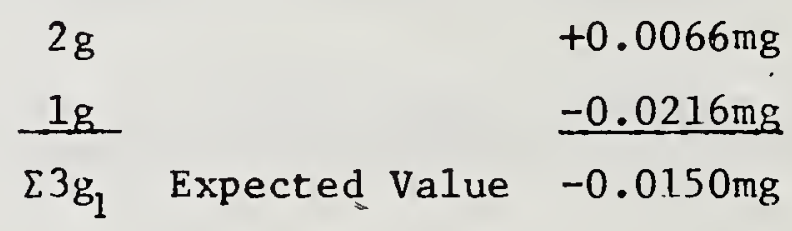

Series 3: $\quad \sum 3 g_{2}$

\begin{tabular}{cr}
$2 \mathrm{~g}$ & $+0.0066 \mathrm{mg}$ \\
$500 \mathrm{mg}$ & $-0.0005 \mathrm{mg}$ \\
$300 \mathrm{mg}$ & $-0.0041 \mathrm{mg}$ \\
$200 \mathrm{mg}$ & $-0.0049 \mathrm{mg}$ \\
\hline$\Sigma 3 \mathrm{~g}_{2}$ Expected Value & $-0.0029 \mathrm{mg}$
\end{tabular}


Series 4: $\sum 300 \mathrm{mg}$

\begin{tabular}{|c|c|c|}
\hline Weight & & $\begin{array}{c}\text { Apparent Mass } \\
\text { Value }\end{array}$ \\
\hline $200 \mathrm{mg}$ & & $-0.0049 m g$ \\
\hline $100 \mathrm{mg}$ & & $+0.0008 \mathrm{mg}$ \\
\hline $300 \mathrm{mg}_{1}$ & Expected Value & $-0.0041 \mathrm{mg}$ \\
\hline
\end{tabular}

Series 4: $\quad\left[300 \mathrm{mg}_{2}\right.$

\begin{tabular}{|c|c|c|}
\hline $200 \mathrm{mg}$ & & $-0.0049 \mathrm{mg}$ \\
\hline $50 \mathrm{mg}$ & & $+0.0074 \mathrm{mg}$ \\
\hline $30 \mathrm{mg}$ & & $-0.0049 \mathrm{mg}$ \\
\hline $20 \mathrm{mg}$ & & $-0.0020 \mathrm{mg}$ \\
\hline$\sum 300 \mathrm{mg}_{2}$ & Expected Value & $-0.0044 \mathrm{mg}$ \\
\hline
\end{tabular}

Series 5: $\sum 30 \mathrm{mg}_{1}$

\begin{tabular}{ll}
$20 \mathrm{mg}$ & $\begin{array}{r}-0.0020 \mathrm{mg} \\
10 \mathrm{mg}\end{array}$ \\
\hline$\sum 30 \mathrm{mg}_{1} \quad$ Expected Value & $+0.0028 \mathrm{mg}$ \\
\hline$+0.0008 \mathrm{mg}$
\end{tabular}

Series 5: $\quad \Sigma 30 \mathrm{mg}_{2}$

\begin{tabular}{|c|c|c|}
\hline $20 \mathrm{mg}$ & & $-0.0020 \mathrm{mg}$ \\
\hline $5 \mathrm{mg}$ & & $+0.0065 \mathrm{mg}$ \\
\hline $3 \mathrm{mg}$ & & $+0.0030 \mathrm{mg}$ \\
\hline $2 \mathrm{mg}$ & & $-0.0142 \mathrm{mg}$ \\
\hline$\sum 30 \mathrm{mg}_{2}$ & Expected Value & $-0.0067 \mathrm{mg}$ \\
\hline
\end{tabular}


Series 6: For weighing 5mg - $55 \mathrm{mg}$

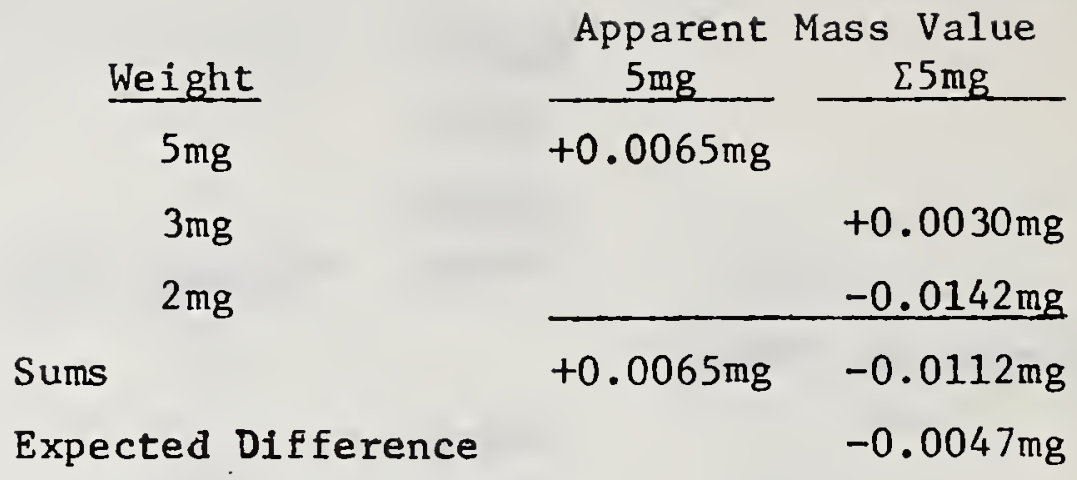

Series 6: For weighing $3 \mathrm{mg}-\sum 3 \mathrm{mg}$

\begin{tabular}{|c|c|c|c|}
\hline & & $3 \mathrm{mg}$ & $\sum 3 \mathrm{mg}$ \\
\hline & $3 \mathrm{mg}$ & $+0.0030 \mathrm{mg}$ & \multirow[b]{2}{*}{$-0.0142 \mathrm{mg}$} \\
\hline & $2 \mathrm{mg}$ & & \\
\hline \multirow{2}{*}{\multicolumn{2}{|c|}{$1 \mathrm{mg}$}} & & $+0.0091 \mathrm{mg}$ \\
\hline & & $+0.0030 \mathrm{mg}$ & $-0.0051 \mathrm{mg}$ \\
\hline Expecte & ed Difference & $-0.0021 \mathrm{mg}$ & \\
\hline
\end{tabular}




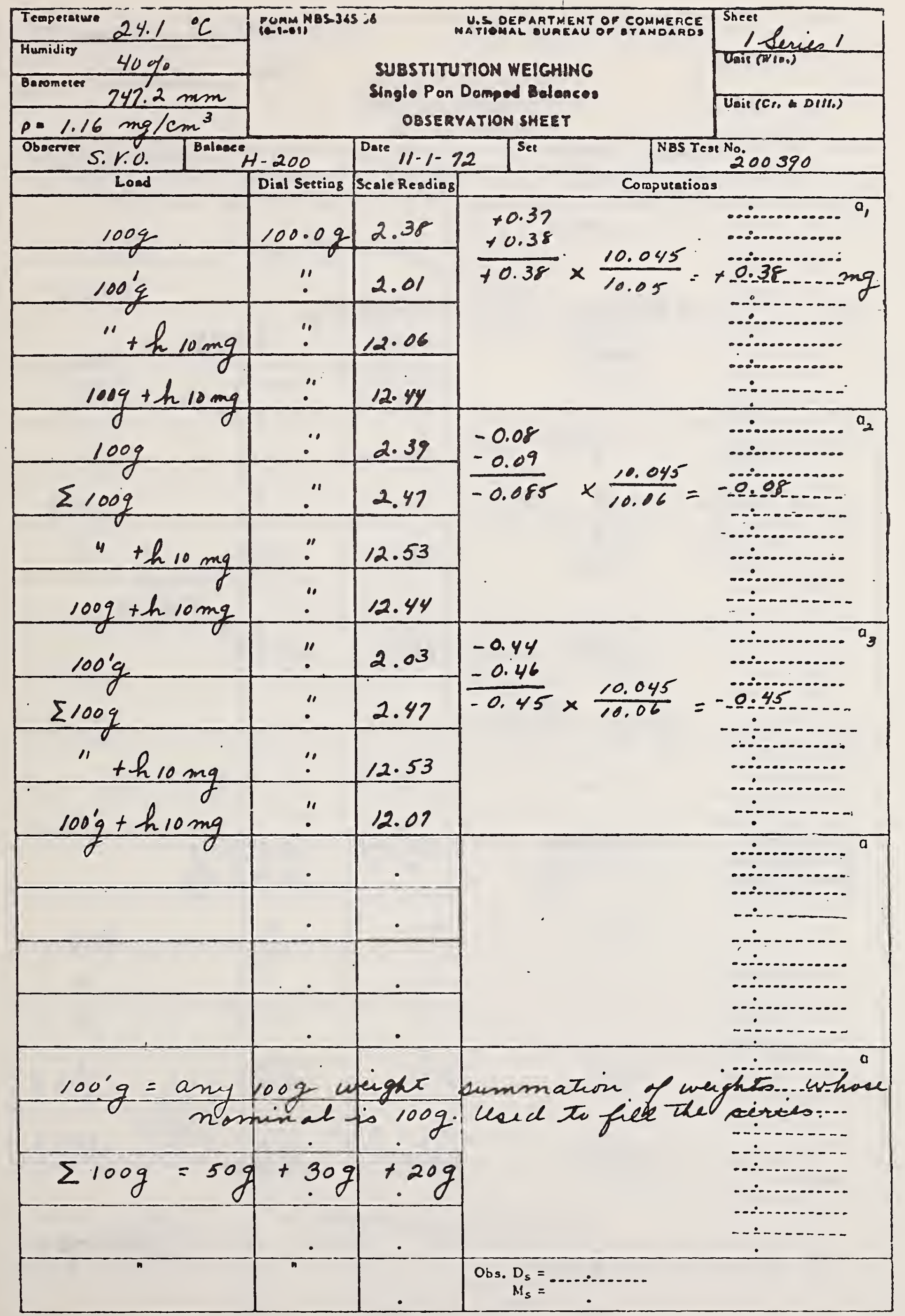

$-63-$ 
Sheet 2 Leries,

Date $11-1-12$

sed. $1,1_{1}, 1_{2}$
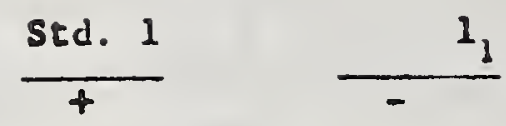

$+$

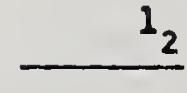

2

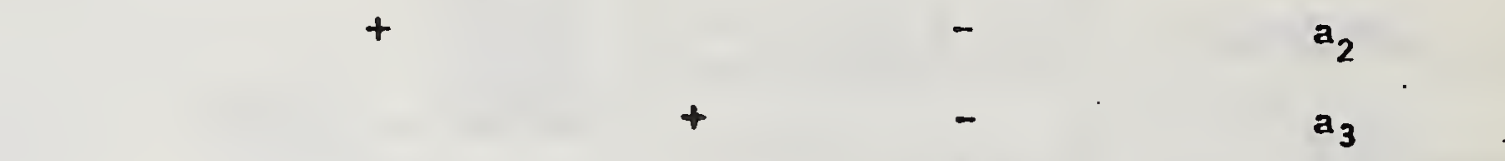

x-A ld Cor. Std. I $=-0.058 \mathrm{mg}$

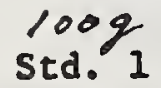

$a_{1}+0.38$

$a_{2}=0.08$

$a_{3}-0.45$

$k=0.058$

Sun $=$

$d=$

Surn/d

$-\Delta \rho \Lambda V$

Est. True

liass Cor.

App. ilass vs.

Brass Cor.

accepted Cor. from Repert

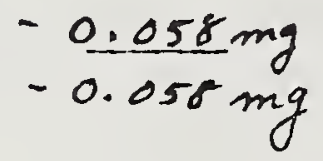

$$
\underline{\Delta_{1}}
$$

${ }_{1}+0.38$

$a_{2}=0.08$

$a_{3}-0.45$

Surn $=$

$\frac{3}{-0.058}$

$\overline{0.058 \mathrm{mg}}$
$0.058 \mathrm{mg}$

1

$-1$

$\frac{1}{+0.01}$

$\mathrm{d}=$

Sum $/ d=$
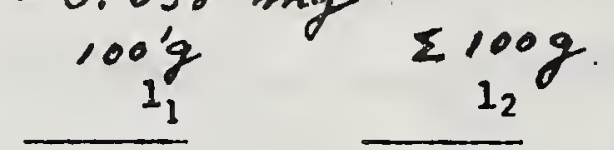

$-2$

$-1$

1

$\frac{3}{-1.304}$

$\frac{3}{-0.435}$

$-\frac{0.435 \mathrm{mg} g}{*}$

$\underline{\Delta_{2}}$

$-1$

1

$\frac{-1}{-0.01}$

$-\frac{3}{-0.0033}$

$\frac{3}{+0.056}$

$\frac{3}{+0.019}$

$\frac{3}{+0.0033}$
Check

$-1$

$-3$

$-2$

$-3$

$-1$

0

9
$\Sigma$ dowm

$\Sigma$ across $+\frac{0.019}{+0.007 \mathrm{mg}}$

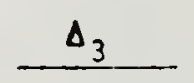

Check

1

$-1$

$-1$

5. dorn

$\Sigma$ across

* This is an unknown

$$
\mathrm{s}=\sqrt{\left(i_{1}\right)^{2}+\left(i_{2}\right)^{2}+\left(i_{3}\right)^{2}}=
$$




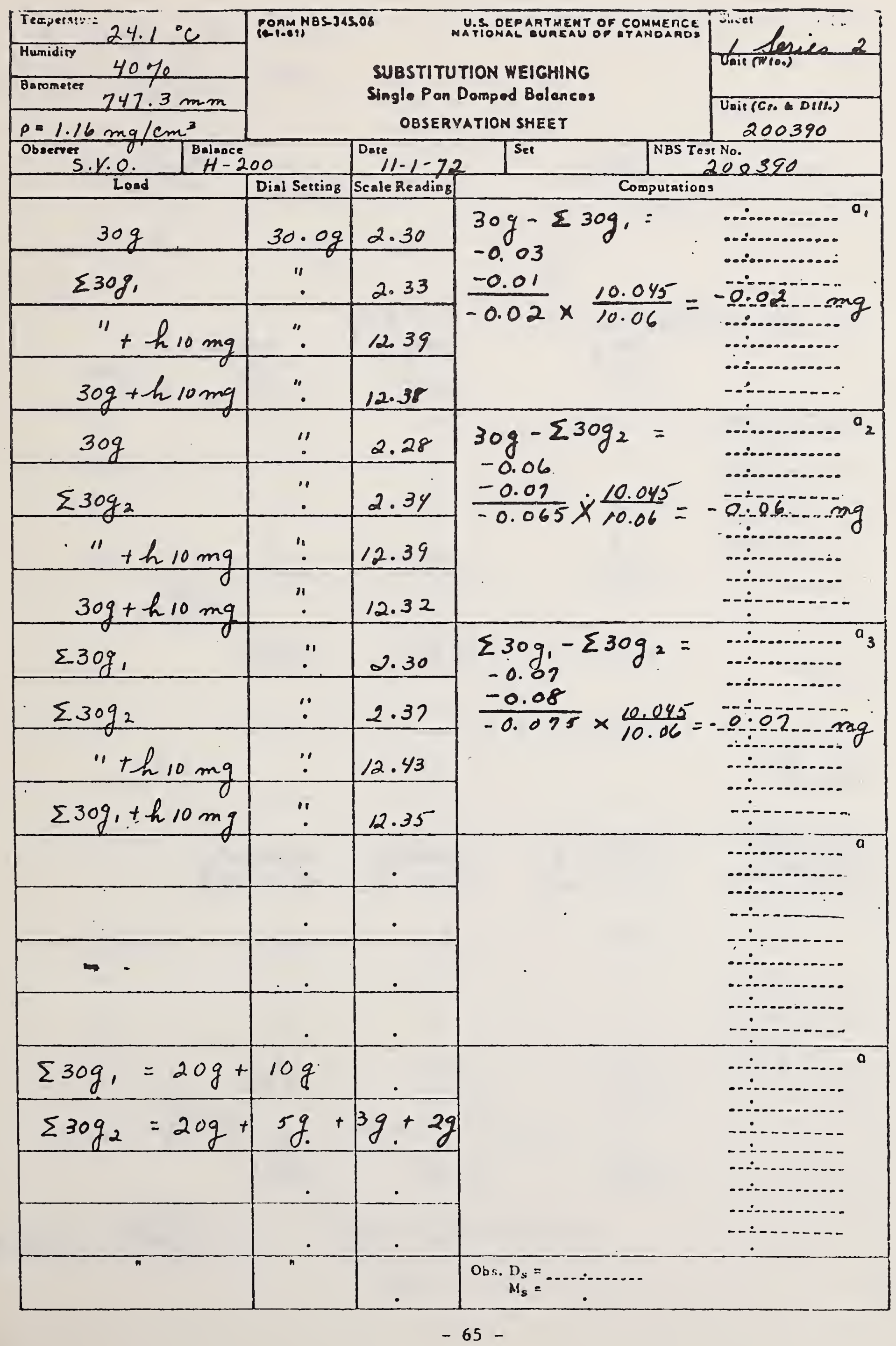


Shee 2 Leries 2

Date $11-1-72$

std. $1, I_{1}, 1_{2}$

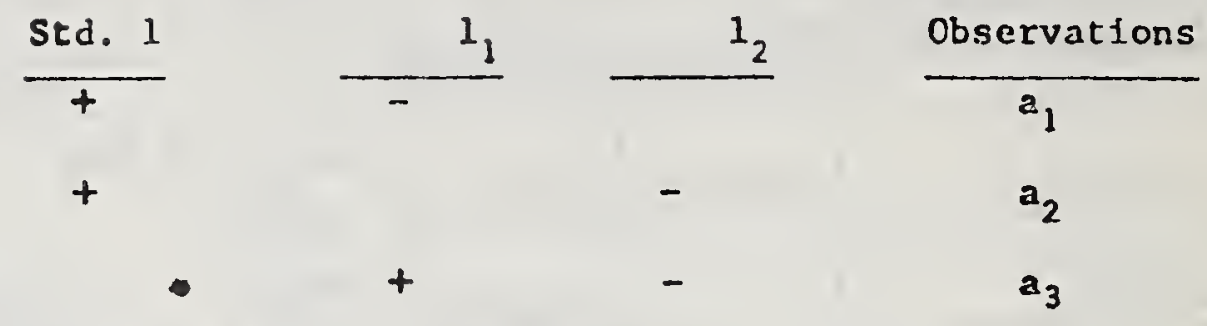

$x$ - A H Cor. Std. $I=-0.0 / 3 \mathrm{mg}$
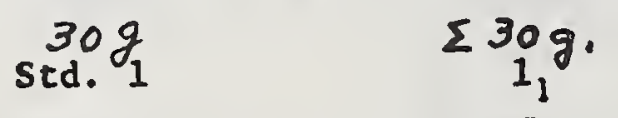

$a_{1}-0.02$

0

$a_{2}-0.06$

$a_{3}-0.07$

K $\quad-0.013$

Surs $=$

d $=$

Sum /d

$-\Delta \rho \Delta V$

Est. True

llass Cor.

App. Ilass vs.

Brass Cor.

Ccceptad Cor. from Report

$-0.013 \mathrm{mg}$
$-0.013 \mathrm{mg}$

$$
\Delta_{1}
$$

$a_{1-0.02}$

1

$a_{2}-0.06$

$-1$

$a_{3}-0.07$

$$
\frac{1}{-0.03}
$$

Sur1 =

$-\frac{3}{-0.01}$

d $=$
$-2$

$-1$

1

$\frac{3}{-0.009}$

$\frac{3}{-0.003}$


$\begin{array}{ll}-0.003 \mathrm{mg} & +0.057 \mathrm{mg} \\ -0.005 \mathrm{mg} & +0.053 \mathrm{mg}\end{array}$

$\Delta_{2}$

$-1$

$\Delta_{3}$

Check

1

1

1

$\frac{-1}{+0.03}$

$\frac{1}{-0.03}$

$\Sigma$ dorn

$\Sigma$ across

$\Sigma$ across

$\frac{3}{+0.057}$
Check

$-3$

$-3$

0

9

Siunt $/ \mathrm{dl}=$

$$
\begin{gathered}
s=\sqrt{\left(i_{1}\right)^{2}+\left(i_{2}\right)^{2}}+\sqrt{\left(i_{3}\right)^{2}}=\sqrt{3 \times 10^{-4}}=0.17 \mathrm{mg} \\
-66-
\end{gathered}
$$




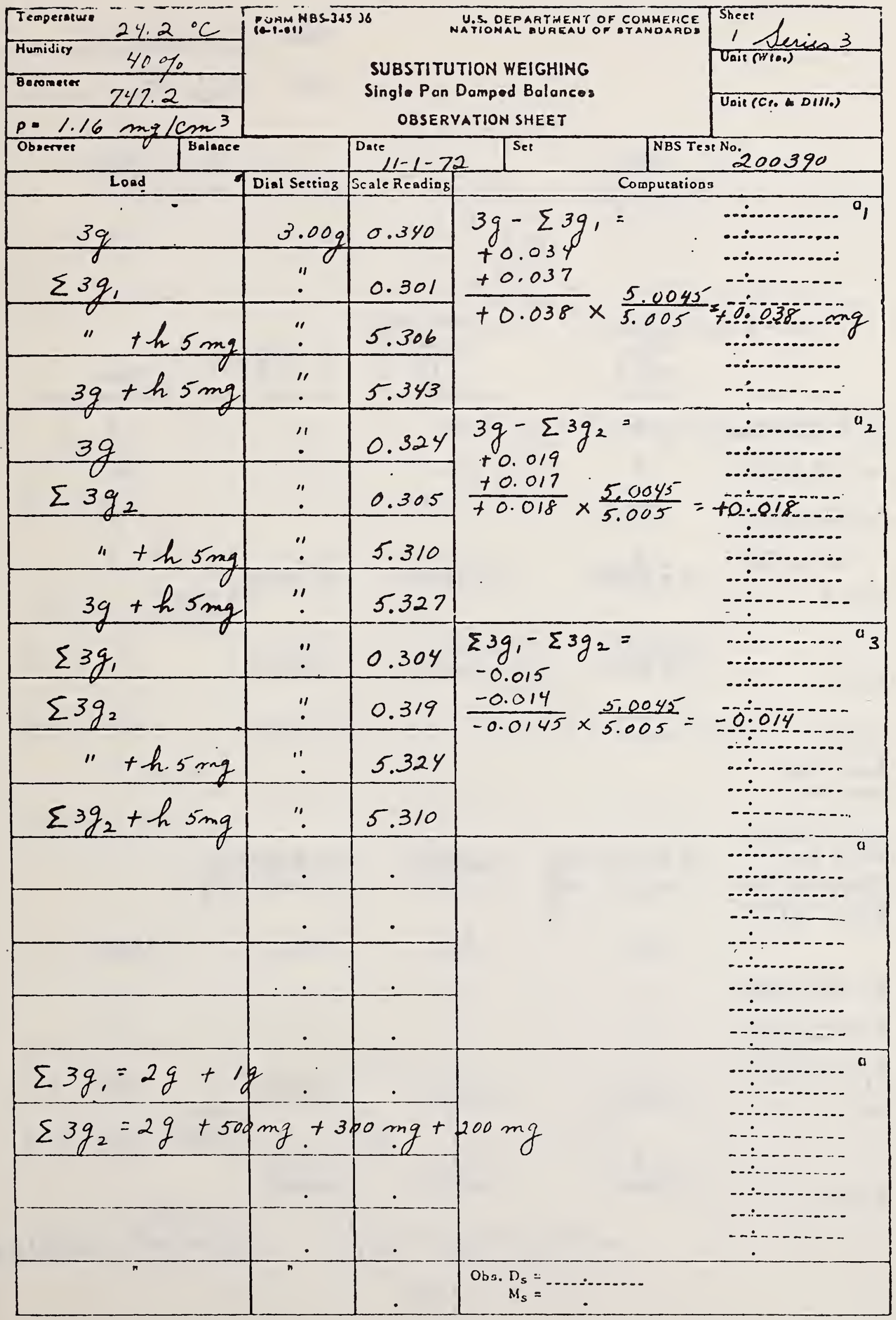

$-67-$ 
sheet 2 Series 3

Date $11-1-72$

std. $1,1_{1}, 1_{2}$

$\frac{\text { std. } 1}{+}$

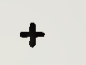

$1_{2} \quad \frac{\text { Observations }}{a_{1}}$

$a_{2}$

$a_{3}$

$K$ - A $M$ Cor. Std. $1=+0.0191 \mathrm{mg}$

std. 1

$\sum_{12}^{3} g_{2}$

Check

$\frac{\sum 3 g,}{1_{1}}$

$-1$

$-3$

$a_{1}+0.038 \mathrm{eng}$

$a_{2}+0.018$

$-1$

$-2$

$-3$

$a_{3}=0.014$

0
+0.0573

1

- -1

0

$k+0.0191$

$\frac{3}{-0.0507} \quad \frac{3}{-0.0027}$

9

Sura $=$

$\Sigma$ down

$d=$

$\frac{3}{-0.0139} \quad \frac{3}{-0.0009}$

$\Sigma$ across

Sum /d

$\frac{3}{+0.0191}$

$+0.0027$

Est. True

lias Cor.

App. lias vs.

$\begin{array}{llll}\text { Brass Cor. } & +0.0191 \mathrm{mg} & -0.0139 & +0.0018 \mathrm{mg} \\ \text { Accepted car. } & 0.0191 \mathrm{mg} & -0.0150 & -0.0027 \mathrm{mg}\end{array}$

from Report $+0.0191 \mathrm{~m}$

$\begin{array}{ccr}\frac{\Delta_{2}}{-1} & \frac{\Delta_{3}}{1} & \text { Check } \\ 1 & -1 & 1 \\ -\frac{-1}{-0.006} & +\frac{1}{0.006} & -1\end{array}$

$a_{1}+0.038$

$\frac{\Delta_{1}}{1}$

$a_{2} \pm 0.018 \quad-1$

$a_{3}=0.014$

Sura =

$\frac{1}{+0.006}$

$\Sigma$ dorm

$\sum$ across

d $=$

$\frac{3}{-0.002}$

$\frac{3}{-0.002}$

Sum $/ d=$

$\frac{3}{10.002}$

$s=V^{-}\left(i_{1}\right)^{2}+\left(i_{2}\right)^{2}+\left(\dot{i}_{3}\right)^{2} \quad \Rightarrow \quad \sqrt{12 \times 10^{-6}}=0.0035 \mathrm{mg}$

$-68-$ 


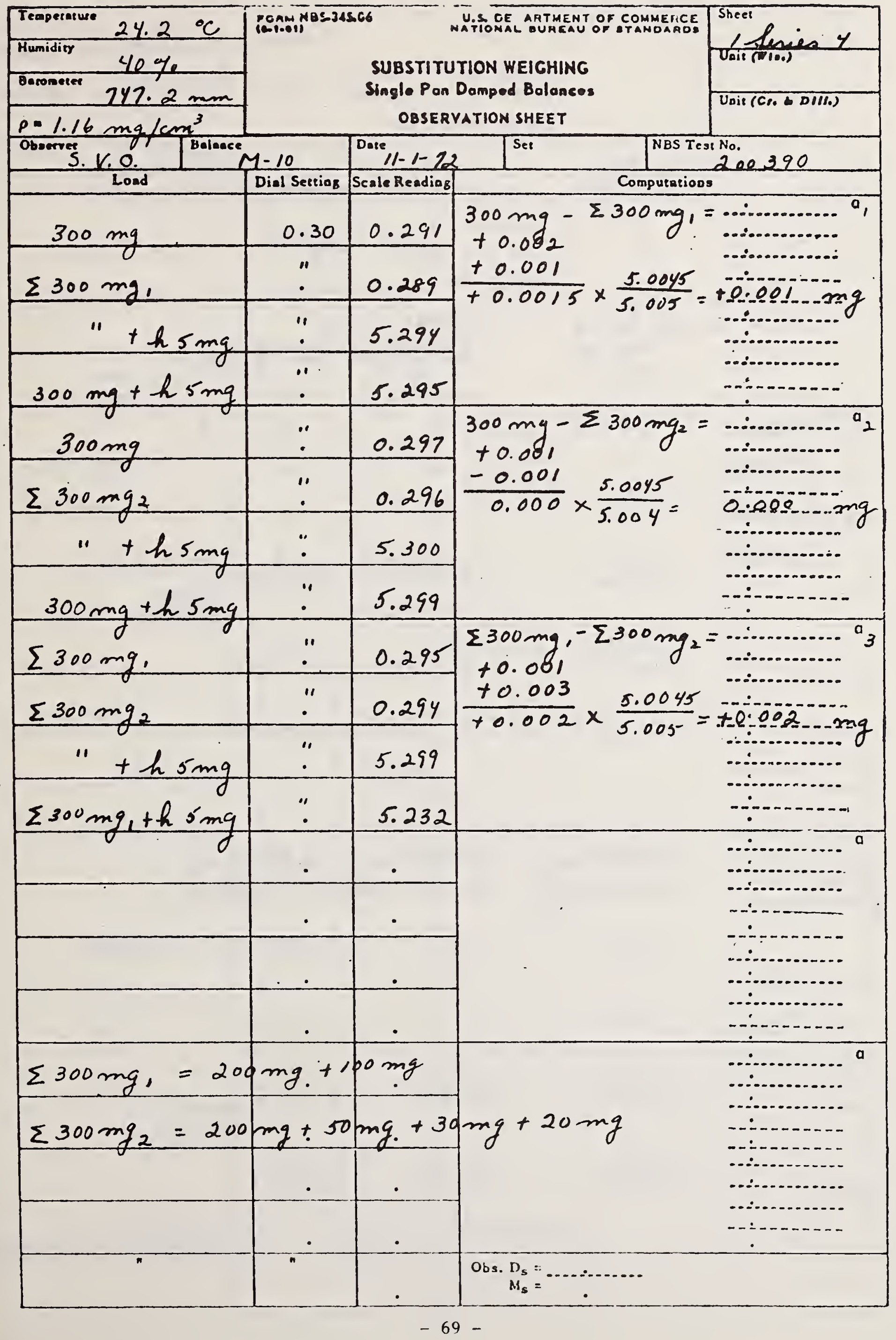


Sheet 2 Leries 4

Date $11-2-72$

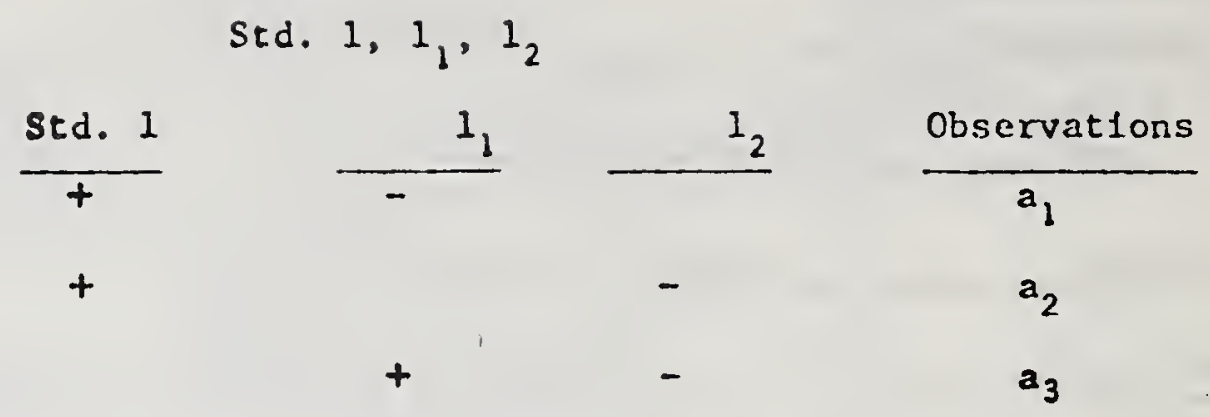

$K$ - A H Cor. Std. $1=-0.0040 \mathrm{mg}$

$a_{1}+0.001$

$a_{2}-0.000$

$2_{3}+0.002$

$\therefore=0.0040$

Sun $=$

d $=$

Surn/d

$-\Delta \rho \Delta V$

Est. True

liass Cor.

A.pp. IIass vs.

Brass Cor.

Acapted Cor.

from Report

$-0.0040 \mathrm{mg}$
$-0.0040 \mathrm{mg}$

$\Delta_{1}$

$e_{1}+0.001$

$a_{2}-0.000$

$a_{3}+0.003$

Surn $=$

d $=$

Stu: $/ d=$

1

$-1$

$+\frac{1}{0.003}$

$+\frac{3}{0.001}$

$$
\begin{aligned}
& 300 \mathrm{mg} \\
& \text { std. } 1
\end{aligned}
$$

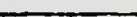

0

0

0

$-\frac{3}{-0.0120}$

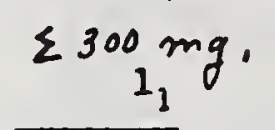

${ }_{\Sigma} 300 \mathrm{mg}_{2}$

$\frac{3}{-0.0040}$

$$
-2
$$

$-1$

1

$\frac{3}{-0.0120}$

$\frac{3}{-0.0040}$

$-0.0040 \mathrm{mg}-0.0056 \mathrm{mg}$
$-0.0041 \mathrm{mg}-0.0044 \mathrm{mg}$

$\Delta_{2}$

$\Delta_{3}$

$-1$

$\frac{3}{-0.0150}$

$\sum$ down

$\Sigma$ across

Check

$-3$

$-3$

0

9 


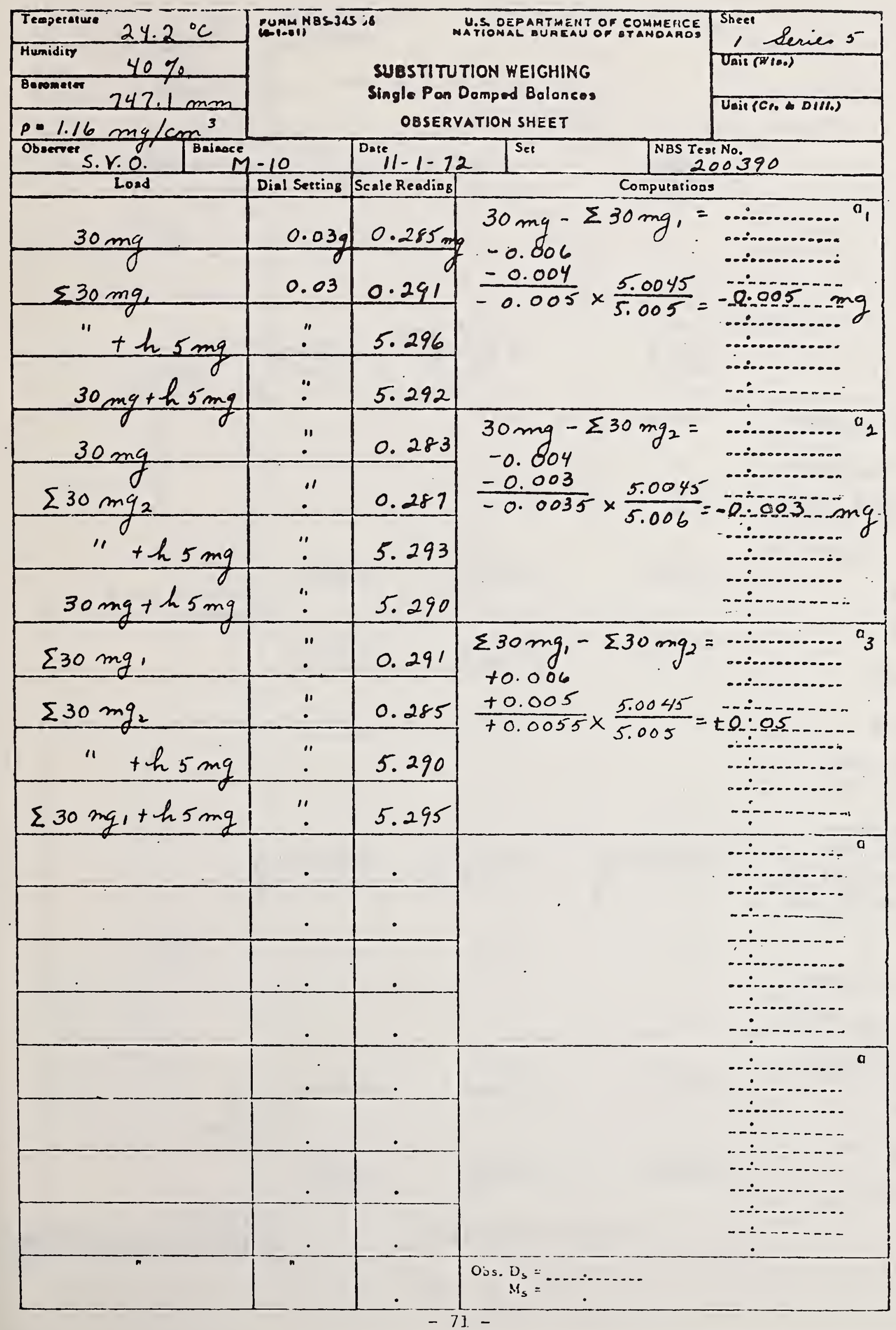


Sheet 2 Series 5

Date $11-2-72$

std. $1,1_{1}, 1_{2}$

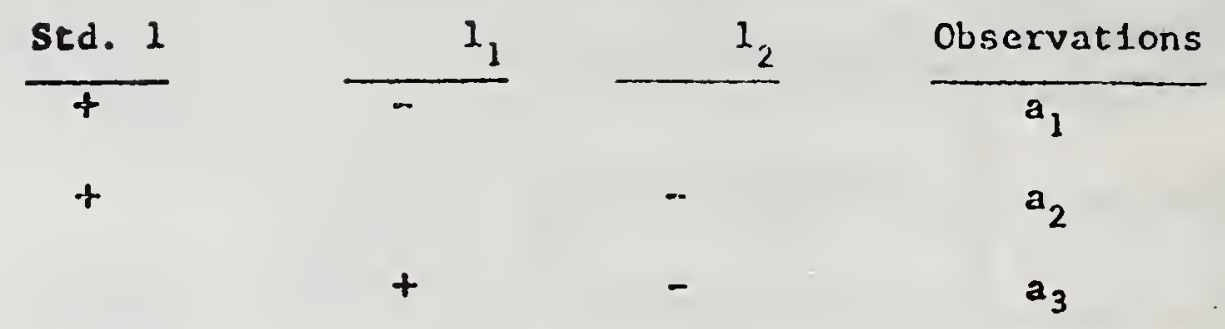

K - A H Cor, St:A. $1=-0.0049 \mathrm{mg}$

$$
\begin{aligned}
& 30 \mathrm{mg} \\
& \text { std. } 1
\end{aligned}
$$

$a_{1}-0.005$

$a_{2}=0.003$

$a_{3}+0.005$

k. -0.0049

Surs $=$

$d=$

Surild

$-\Delta \rho \Delta V$

Est. True

liass Cor.

App. Ilass vs.

Brass Cor.

Acceptiel Cor. from Report

i. $-0,005$.

$a_{2}-0.003$

$a_{3}+0.005$

surn $=$

d $=$

$\operatorname{sum} / d=$

$\frac{3}{-0.0049}$

$\Delta_{1}$

$\frac{1}{+0.003}$

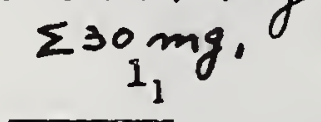

$\sum 30 \underset{I_{2}}{\mathrm{mg}}$

Check

$-2$

$-i$

$-3$

$-1$

$-2$

$-3$

1

$-1$

0

$\frac{3}{+0.0033}-\frac{3}{-0.0087}$

$\Sigma$ down

$\Sigma$ across

$\frac{3}{+0.0011} \quad \frac{3}{-0.0029}$

$-0.0049 m g$
$-0.0049 m g$

$+0.0011 \mathrm{mg}-0.0029 \mathrm{mg}$
$+0.0008 \mathrm{mg}-0.0061 \mathrm{mg}$

$\Delta_{2}$

$b_{3}$

Check

$-1$

1

了.

I

$-1$

$-3$

$-0.003$

$\frac{1}{+0.003}$

1. doun

I. across 


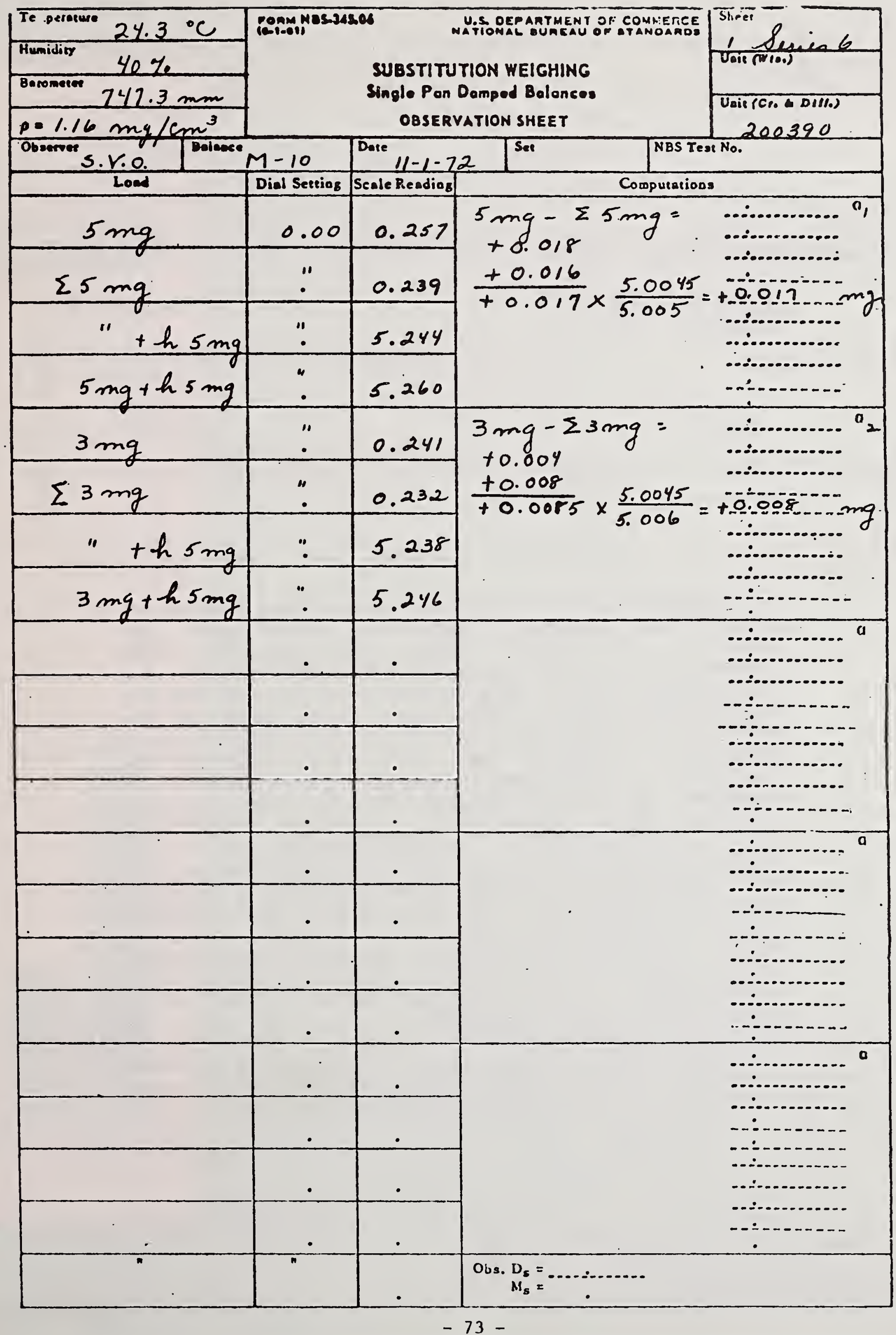


MBS.114A IREV. 7.73 )

\begin{tabular}{|c|c|c|}
\hline $\begin{array}{l}\text { 1. PIIBI.IC AIION OK RI:I'OKT N(). } \\
\text { NBSIR 76-999 }\end{array}$ & $\begin{array}{l}\text { 2. Gov't Accession } \\
\text { No. }\end{array}$ & 3. Raripient's Accession No. \\
\hline \multirow{2}{*}{\multicolumn{2}{|c|}{ 4. TITI.I: AND SUBTITI.I: }} & $\begin{array}{l}\text { 5. Publication Date } \\
\text { February } 1976\end{array}$ \\
\hline & & 6. Performing Organization Code \\
\hline 7. AUTHOR(S) & er & $\begin{array}{l}\text { 8. Performing Organ. Report No. } \\
\text { NBSIR 76-999. }\end{array}$ \\
\hline & 10. Project/Task/Work Unit No. \\
\hline \multicolumn{2}{|l|}{$\begin{array}{l}\text { DEPARTMENT OF COMMERCE } \\
\text { WASHINGTON, D.C. } 20234\end{array}$} & 11. Contract/Grant No. \\
\hline \multirow{2}{*}{\multicolumn{2}{|c|}{ 12. Sponsoring Organization Name and (Completc Address (Street, City, State, ZIP) }} & $\begin{array}{l}\text { 13. Type of Report \& Period } \\
\text { Covered } \\
\text { Final }\end{array}$ \\
\hline & & 14. Sponsoring Agency Code \\
\hline
\end{tabular}

15. SUPPI.EMENTARY NOTIS

16. A BSTRAC.T (A 200-word or less factual summary of most significant information. If document includes a significant bibliography or literature survey, mention it here.)

Surveillance tests are designed to monitor the values of mass standards between calibrations. Two types are described; both consist of comparisons of the weights of an ordered set of mass standards with each other. The differences found are compared with those computed from the reported mass values. Surveillance limits based on the precision of both the calibration and the surveillance test processes are computed. These limits are estimates of the departure of the measured differences from the expected, or predicted, differences as computed from the reported values. A larger change is considered significant. Additional measurements to identify individual weights which have changed are required when a given comparison indicates that the mass of one or more of the weights involved has changed. Buoyancy corrections are used to correct for the difference in the buoyant effect on weights of differing densities. Records document the surveillance test results, and control charts help detect trends. Judgments concerning recalibration can be made based on the constancy of the weights and the use requirements.

17. KEY WORI)S (six to twelve entries; alphabetical order, capitalize only the tirst letter of the tirst key word unless a proper name; separated by semicolons) Apparent mass; buoyancy; buoyancy correction; change;

comparison; difference; mass; records; set; surveillance limits; surveillance test; test interval; true mass; value; weighing design; weights.

18. AVAII.ABII.ITY $(X)$ IJnlimiced

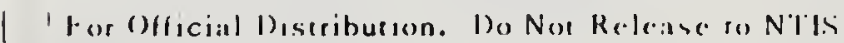

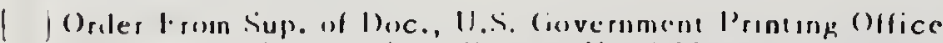

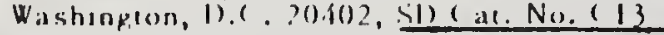

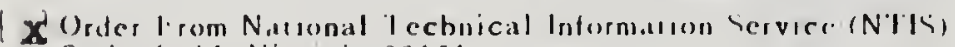
Springficllal, Virkinia 22151

\begin{tabular}{|c|c|}
\hline $\begin{array}{l}\text { 19. SIE( IIRITY CI.ASS } \\
\text { (THIS RISPORT) } \\
\text { UNC I. ASSII-III) }\end{array}$ & $\begin{array}{l}\text { 21. NO. OF PAGES } \\
77\end{array}$ \\
\hline $\begin{array}{l}\text { 20. SIC UKIIY ( I.ASS } \\
\text { (IIIIS I'A(ES) }\end{array}$ & 22. Price \\
\hline INR I.ASSII:11:1) & $\$ 5.00$ \\
\hline
\end{tabular}

